\title{
Review \\ The Clinical Impact of the EPH/Ephrin System in Cancer: Unwinding the Thread
}

\author{
Alexandros Pergaris ${ }^{+}\left(\mathbb{D}\right.$, Eugene Danas ${ }^{\dagger}$, Dimitrios Goutas $\mathbb{D}^{(D}$, Alexandros G. Sykaras $\mathbb{D}^{\text {D }}$, Angelos Soranidis \\ and Stamatios Theocharis *
}

check for updates

Citation: Pergaris, A.; Danas, E.; Goutas, D.; Sykaras, A.G.; Soranidis, A.; Theocharis, S. The Clinical Impact of the EPH/Ephrin System in Cancer: Unwinding the Thread. Int. J. Mol. Sci. 2021, 22, 8412. https://doi.org/ $10.3390 /$ ijms 22168412

Academic Editor: Rafael Pulido

Received: 30 June 2021

Accepted: 30 July 2021

Published: 5 August 2021

Publisher's Note: MDPI stays neutral with regard to jurisdictional claims in published maps and institutional affiliations.

Copyright: (c) 2021 by the authors. Licensee MDPI, Basel, Switzerland. This article is an open access article distributed under the terms and conditions of the Creative Commons Attribution (CC BY) license (https:// creativecommons.org/licenses/by/ $4.0 /)$.
First Department of Pathology, Medical School, National and Kapodistrian University of Athens, 11527 Athens, Greece; alexperg@yahoo.com (A.P.); eugenedanas@gmail.com (E.D.); dimgoutas@med.uoa.gr (D.G.); alexander.sykaras@gmail.com (A.G.S.); angelossoranidis@hotmail.com (A.S.)

* Correspondence: stamtheo@med.uoa.gr; Tel.: +30-210-7462116; Fax: +30-210-7456259

+ Equal contribution.

Abstract: Erythropoietin-producing human hepatocellular receptors (EPHs) compose the largest known subfamily of receptor tyrosine kinases (RTKs). They bind and interact with the EPH family receptor interacting proteins (ephrins). EPHs/ephrins are implicated in a variety of physiological processes, as well as in cancer pathogenesis. With neoplastic disease remaining a leading cause of death world-wide, the development of novel biomarkers aiding in the field of diagnosis, prognosis, and disease monitoring is of utmost importance. A multitude of studies have proven the association between the expression of members of the $\mathrm{EPH} /$ ephrin system and various clinicopathological parameters, including disease stage, tumor histologic grade, and patients' overall survival. Besides their utilization in timely disease detection and assessment of outcome, EPHs/ephrins could also represent possible novel therapeutic targets. The aim of the current review of the literature was to present the existing data regarding the association between $\mathrm{EPH} /$ ephrin system expression and the clinical characteristics of malignant tumors.

Keywords: EPHs; ephrins; biomarkers; cancer; diagnosis; prognosis; treatment

\section{Introduction}

Neoplastic disease remains a leading cause of death, with approximately 19.3 million new cancer cases diagnosed in 2020 worldwide, accompanied by an estimated 10 million cancer-related deaths [1]. Furthermore, according to the National Cancer Institute, an estimated $39.5 \%$ of men and women will be diagnosed with cancer at some point during their lifetime [2]. Such statistics indicate the heavy impact of neoplasia on patients' welfare, healthcare systems, and socio-economic stability. Despite ongoing advances in therapeutic interventions, further research is called for to combat the immense challenge imposed by neoplasia. Modern studies continue to shed light on the molecular mechanisms implicated in key steps of cancer pathogenesis, such as tumor formation and growth, invasion, lymphand angiogenesis, as well as distant dissemination. The development of novel, specialized treatment strategies renders the understanding of these molecular pathways and their clinical impact of paramount importance. Furthermore, the well-established positive effect of early therapeutic intervention on the outcome of cancer patients underlines the need for the discovery of diagnostic, prognostic and predictive biomarkers contributing to timely detection of disease progression and re-currence, as well as assessment of therapeutic outcome. Scientists have shifted their focus on molecules participating in physiologic processes that, when deregulated, can enhance carcinogenesis. Among them, EPHs, with their well-established roles in proliferation, angiogenesis, and cell motility, are speculated to represent key factors in cancer pathogenesis. Therefore, a great number of studies attempted to assess their utilization as diagnostic and prognostic biomarkers, as well as therapeutic targets. 
EPHs compose the largest known subfamily of receptor tyrosine kinases. They bind and interact with the EPH family receptor interacting proteins (ephrins). EPHs are membrane-bound proteins, consisting of an extracellular ephrin-binding domain, a transmembrane region, and a cytoplasmic component that, upon activation, following interaction with a ligand, initiates its RTK activity, activating downstream signaling molecular pathways. Ligand binding activation requires cell-to-cell interaction. Subsequently, as a response, signaling cascades are triggered in the cytoplasm of both the EPH-expressing cell and the ephrin-bearing one, a process termed as backward signaling (Figure 1). Nine EPHA receptors (EPHA1 to EPHA8 and EPHA10), that bind 5 ephrin-A ligands (ephrin-A1 to ephrin-A5), along with 5 EPHB receptors (EPHB1 to EPHB4 and EPHB6), that interact with 3 ephrin-B ligands (ephrin-B1 to ephrin-B3), are expressed in humans. EPHs of a specific subgroup (A or B) show a higher affinity for binding with ephrins belonging to the same subgroup, although inter-subgroup interaction has been frequently observed.

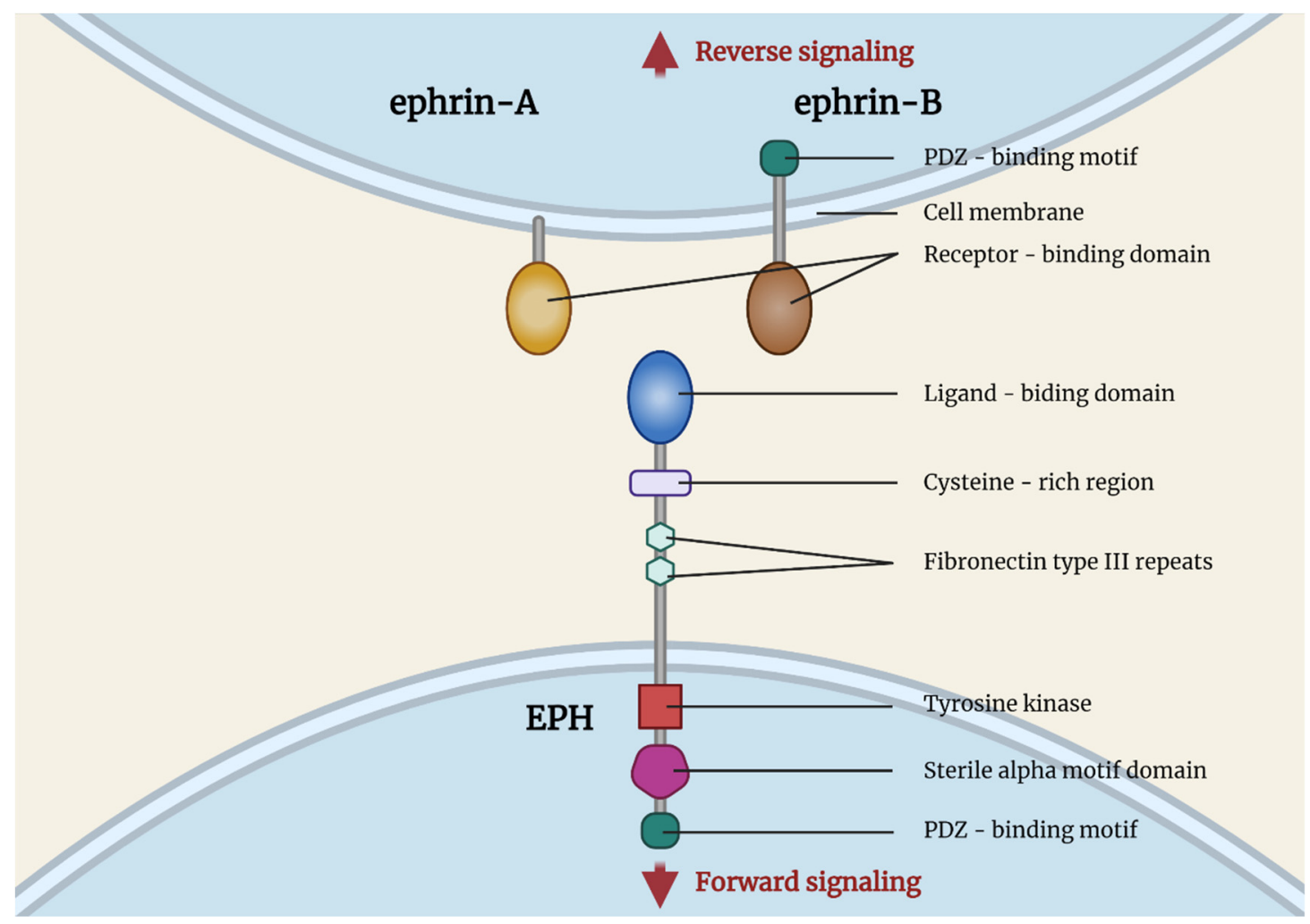

Figure 1. Structure of EPHs/ephrins. Created with BioRender.com (accessed on 2 August 2021).

EPHs/ephrins participate in wide variety of processes in human physiology. They play a pivotal role in cell migration, axon guidance, and synapse formation during embryonic development. They are also implicated in mechanisms like cell adhesion, motility, and cell-matrix interactions, as well as lymphangiogenesis and angiogenesis in response to hypoxia [3].

All the aforementioned processes are vital for tumorigenesis, as cell motility is required for cancer cells' invasion, vessel infiltration, and spreading to distant sites. Moreover, tumors cannot grow beyond a few millimeters without the sprouting of new vessels to provide them with oxygen and nutrients [4]. As accumulating data clearly underlined the clinical implications of EPH/ephrin tumor profiles, many in vivo and in vitro studies focused on revealing the molecular mechanisms through which members of the EPH/ephrin family exert their tumor promoting and tumor suppressive properties. In glioblastoma cell lines, EPHB4, along with its ligand, ephrin-B2, were observed to enhance angiogenesis through interacting with VGFR2 and Notch signaling pathways [5]. EPHA3, on the contrary, seems to enhance apoptosis of lung carcinoma cells via phosphorylation of members 
of the PI3K/BMX/STAT3 signaling pathway [5]. In breast cancer cells, phosphorylation of EPHA3 via Src kinase, due to trastuzumab treatment, induces the activation of PI3K/Akt and MAPK pathways, leading to trastuzumab resistance [5].

Therefore, the implication of the EPH/ephrin system in cell motility, cell-to-cell and cell-matrix interaction, as well as lymph- and angiogenesis renders them a possible key factor in carcinogenesis and an excellent biomarker candidate of tumor promoting and suppressive properties (Figure 2). Indeed, a plethora of studies have attempted to reveal the link between EPH/ephrins and tumorigenesis, as well as tumor characteristics and behavior. Specifically, in solid tumors, researchers have proven the close relationship between the various members of the EPH/ephrin system expression and disease onset and progression. Moreover, therapeutic agents that suppress those mechanisms could represent excellent possible targets for the development of novel, specialized anti-cancer intervention strategies.

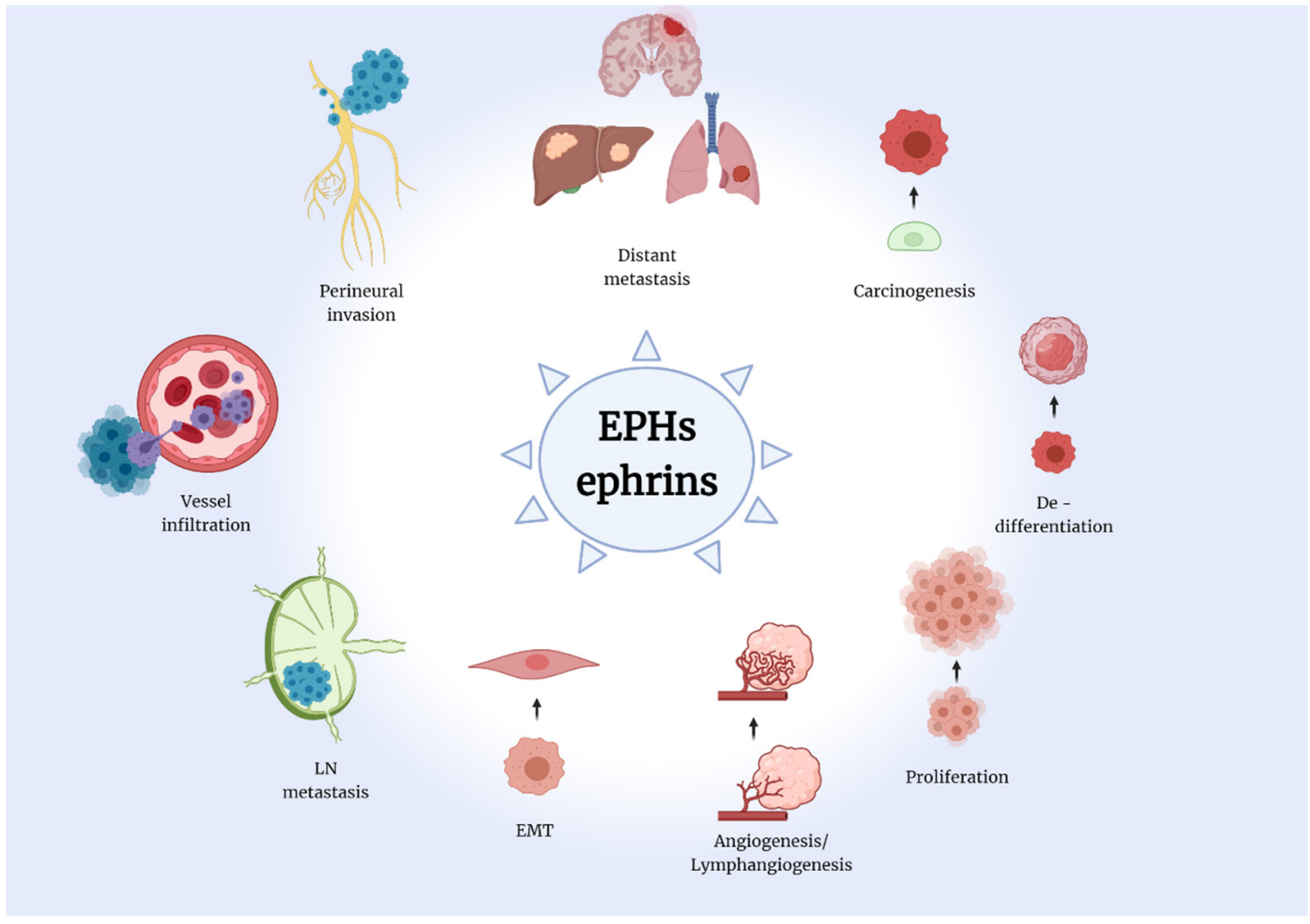

Figure 2. The Eph/ephrin system is implied in a multitude of tumorigenic processes. EPH: erythropoietin-producing human hepatocellular receptors, ephrins: EPH family receptor interacting proteins, EMT: epithelial-mesenchymal transition, LN: lymph nodes. Created with BioRender.com (accessed on 2 August 2021).

In the current review, data regarding the association between EPH/ephrin expression and the clinical characteristics of neoplasia were presented.

\section{Methodology}

We searched, via the pubmed engine, information regarding the role of the members of the EPH/ephrin family in carcinogenesis of solid tumors, focusing on the clinical impact of their expression. The majority of researchers investigated the protein expression of EPHs/ephrins through immunohistochemistry (IHC), IHC in tissue microarrays (TMA IHC), and Western Blot, as well as their mRNA expression, utilizing methods such as the Polymerase Chain Reaction (PCR), reverse-transcription PCR (RT-PCR), and quantitative PCR (q PCR), in a series of tumor specimens from patients with malignant disease. The presence or absence of expression was assessed, as well as the location (nuclear, cytoplasmic or membranous), the staining intensity, and the percentage of positive cells to overall 
tumor cell population. In addition, observations were made regarding different patterns of expression, such as diffuse staining, positive clusters of cells, and increased staining intensity on the tumor invasive front in deeper normal tissue layers. Moreover, most studies investigated the differences in EPHs/ephrins expression by including normal and non-neoplastic tissue samples, either from tissues adjacent to the malignant ones or from healthy individuals. The researchers then proceeded to associate their observations on EPHs/ephrins gene and protein expression with a wide range of clinicopathological parameters, including disease stage, histological grade, presence of lymph node (LN) or distant metastasis, overall survival (OS), and disease-free survival (DFS). Furthermore, the patterns of EPH/ephrin system members expression were correlated to a variety of histological characteristics, such as invasion of vessels, perineural infiltration, Microvessel Density (MVD), level of tumor neo-angiogenesis, and lymphangiogenesis and tumor cell proliferative capacity.

\section{Head and Neck Tumors}

\subsection{Brain}

The impact of the EPH/ephrin system expression in brain tumors is among the most extensively studied, with results suggesting that the aforementioned biomolecules play an overwhelmingly tumor-promoting role on brain cancer pathogenesis [6-12].

\subsubsection{EPHAs}

EPHA2 expression was assessed in normal brain samples and glioma tissues through either IHC or RT-PCR in three studies [6-8]. EPHA2 expression was then correlated with tumor histological features, various clinicopathological parameters, and patients' outcomes. EPHA2 overexpression was positively linked to tumor size [8], higher histological grade of tumors [6,8], peritumoral edema levels [8], and poor patients prognosis [7,8]. EPHA4 expression, on the other hand, exhibited no significant difference between glioblastoma multiforme (GBM) and non-tumoral white matter tissue [9]. EPHA7 immunohistochemical expression was notably absent in the 10 normal brain tissues included in the study and strong in 14 out of 32 cases of primary or recurrent GBM tissues investigated. EPHA7 expression was positively associated with tumor MVD, increased age, and decreased OS [10].

\subsubsection{EPHBs}

In a large study that included 171 tumor samples (29 astrocytomas, 82 GBM, 49 oligodendrogliomas, 11 oligoastrocytomas) and 24 non-tumorous brain specimens from epileptogenic patients, EPHB1, B2, B3, B4, and B6 expression was assessed by quantitative real-time RT-PCR [11]. EPHB1 seemed to have a beneficial influence, since its expression correlated with longer patient OS and was upregulated in oligodendrogliomas, which notably have a more favorable outcome compared to other infiltrating glioma tumors. EPHB2 and EPHB3 expression was reported as higher in neoplastic tissues compared to normal ones, and EPHB4 expression was correlated with shorter patient OS. EPHB4's negative impact was also underlined in another series of 96 primary glioma patients [12], as its expression was positively associated with higher grade and lower Karnofsky Performance Score. Interestingly, EPHB6, along with EPHB1, seems to suppress tumorigenesis. In the aforementioned study by Teng et al [11], EPHB6 expression was reported as lower in neoplastic tissues compared with non-tumorous ones.

\subsubsection{Ephrins}

Ephrin-A1 expression was associated with lower grade gliomas, while patients with tumors positive for EPHA2 and negative for ephrin-A1 exhibited shorter OS and PFS. On the other hand, Tu et al correlated the elevated ephrin-B2 expression to higher-grade tumors and low Karnofsky Performance Score and designated it as an independent negative prognostic factor for progression-free survival of glioma patients [12]. Likewise, ephrin-B3 
seems to negatively impact Central Nervous System neoplasia, with its expression in gliomas reported 2.5-fold higher in tumor samples compared with controls and linked to higher grade tumors [9]. Information concerning the clinical impact of EPH/ephrin expression in brain tumors is summarized in Table 1.

\subsection{Salivary Glands}

In the single study of EPH/ephrin expression in salivary gland tumors, EPHA2 and ephrin-A1 expression were assessed by IHC, Western blot, and real-time RT PCR in 49 primary Adenoid Cystic Carcinomas (ACCs) and 10 normal salivary gland tissues [13]. EPHA2 and ephrin-A1 expression was reported as higher in ACC tissues compared with non-neoplastic ones, and positively correlated with increased MVD. EPHA2 and ephrin-A1 overexpression, along with elevated MVD, was associated with the tumor TNM stage and the presence of perineural and perivascular invasion. Of note, solid type ACCs, which are accompanied by worse prognoses, exhibited higher EPHA2 and ephrin-A1 expression and increased MVD compared with cribriform and tubular subtypes [13].

Fukai et al reported a case of a 29-year-old male ACC patient that presented with perineural spread of the tumor along the mandibular nerve [14]. Tumor cells showed characteristics of Epithelial-Mesenchymal Transition (EMT) and a high expression of EPHA2 (but not ephrin-A1), using IHC, suggesting a possible link between the receptor and aggressive tumor phenotypes. Table 1 and Figure 3 summarize the data concerning EPH/ephrin expression and salivary gland tumors clinicopathological characteristics.

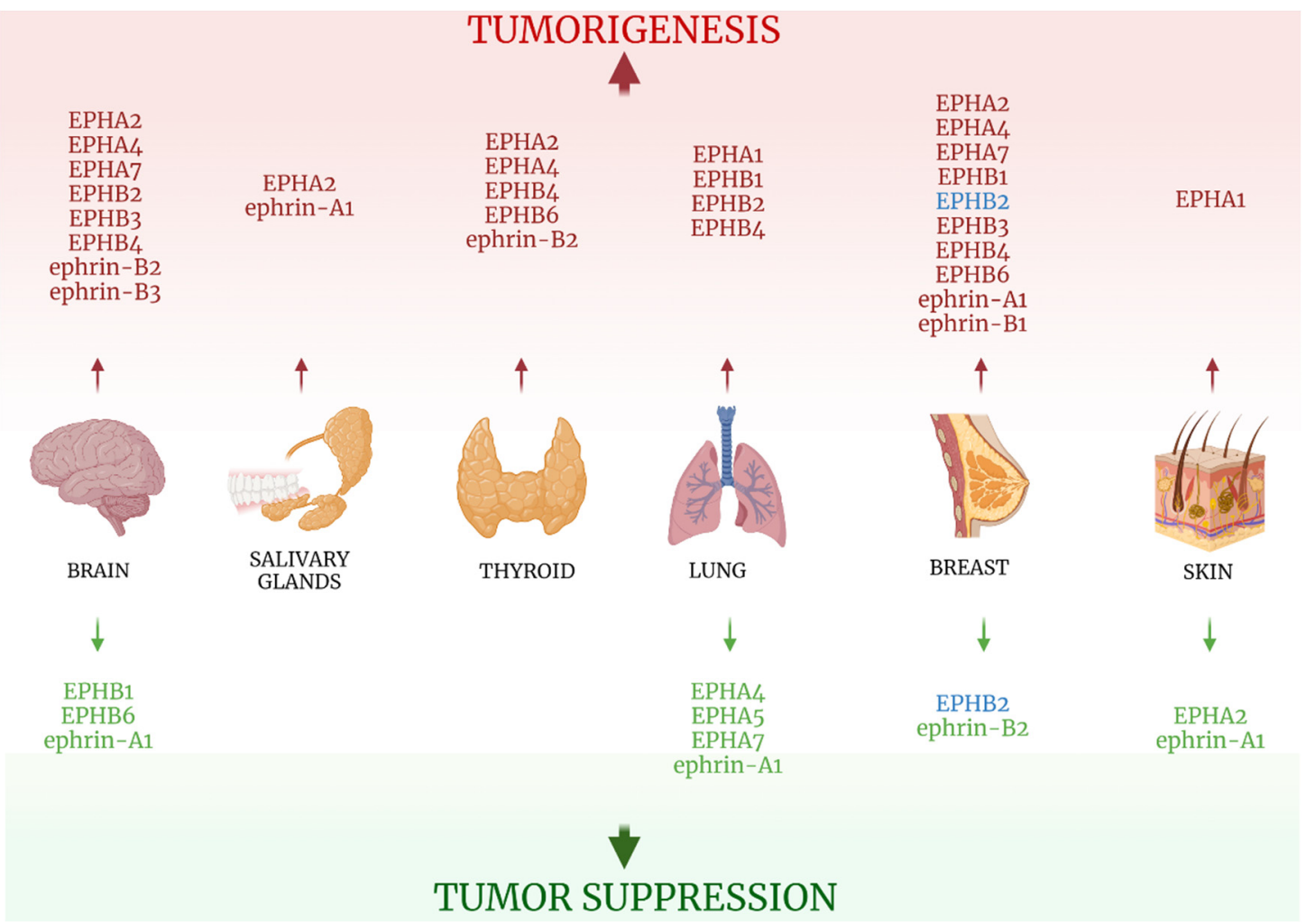

Figure 3. EPH/ephrin family role in solid tumors of the brain, salivary glands, thyroid, lung, breast, and skin. Red-colored EPHs/ephrins enhance tumorigenesis, while green-colored ones suppress it. EPHB2 in breast cancer can play both roles, depending on its location: cytoplasmic EPHB2 expression promotes carcinogenesis, while membranous EPHB2 expression favors tumor-suppression. Created with BioRender.com (accessed on 2 August 2021). 


\subsection{Thyroid \\ 3.3.1. EPHAs}

EPHA2 expression was reported as higher in thyroid carcinoma compared with noncancerous thyroid tissue in two studies [15,16], although no further association with clinicopathological parameters was noted, while EPHA4 showed no difference in expression levels at all [15].

\subsubsection{EPHBs}

In a study that enrolled 46 papillary and 10 follicular thyroid carcinoma tissues, as well as 71 benign thyroid samples, EPHB4 expression was found to be higher in malignant specimens compared with their benign counterparts, while its overexpression was associated with larger tumor sizes [17]. In consistency with those findings, Sharma et al also correlated EPHB4 increased expression with malignancy, as well as with the presence of LN metastasis [18]. It is noteworthy that increased expression of an EPH may hinder tumorigenesis of a certain type of tumor but promote carcinogenesis of another one. The study conducted by Giaginis et al [17] underlined the association between elevated EPHB6 expression and malignancy, tumor size, presence of LN metastasis, capsular, vascular, and lymphatic invasion, as well as increased recurrence rate. Those results are in contrast with the beneficial role of EPHB6 in glioma pathogenesis [11].

\subsubsection{Ephrins}

Ephirn-B2 protein overexpression was correlated with malignant status and LN metastasis [18], while its elevated $m R N A$ expression was linked to higher TNM stage cases [19].

All information on EPH/ephrin expression on thyroid neoplastic tissues is summarized in Table 1 and Figure 3.

Table 1. EPHs/ephrins (bold) studied in solid tumors of head and neck and correlations with clinicopathological parameters.

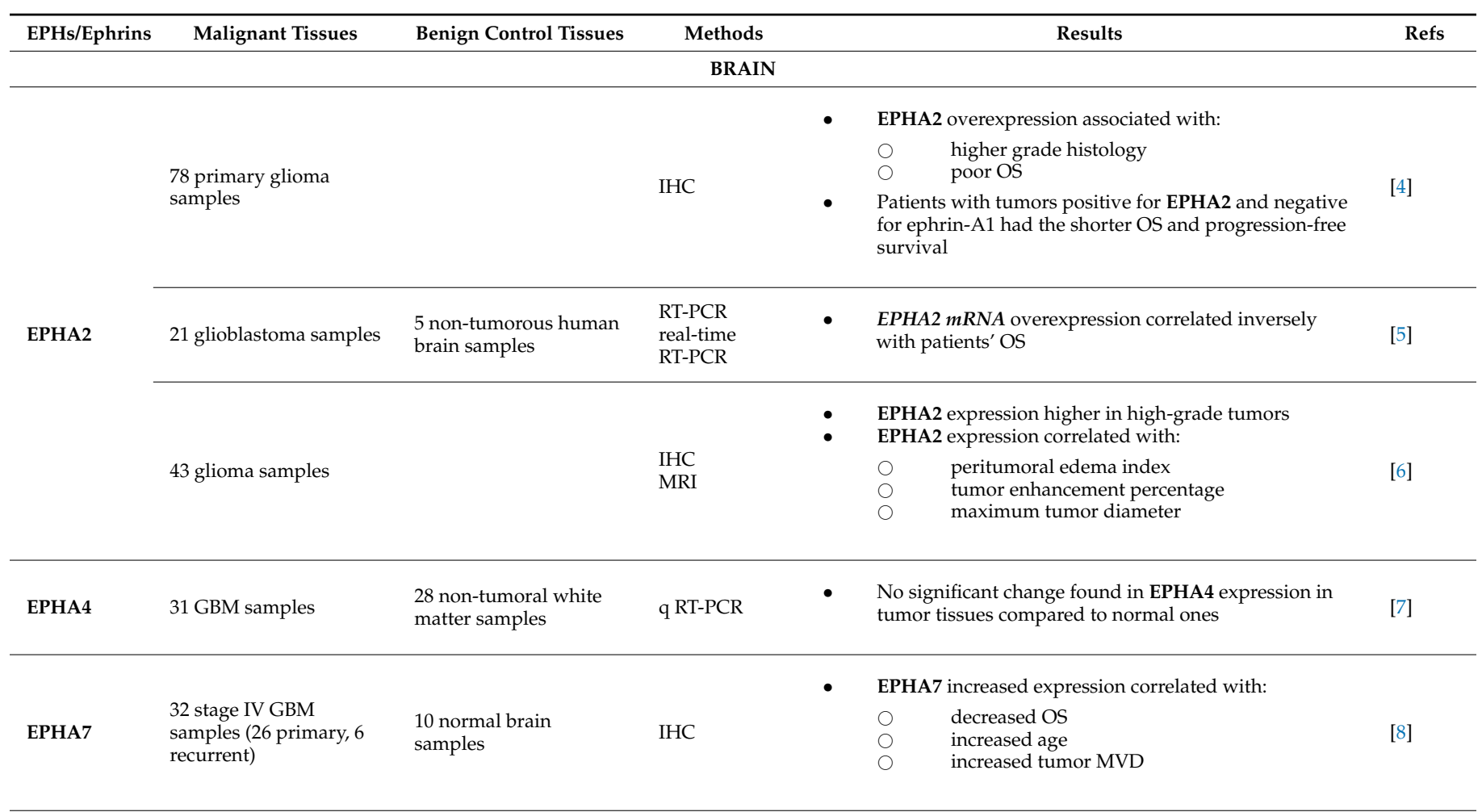


Table 1. Cont.

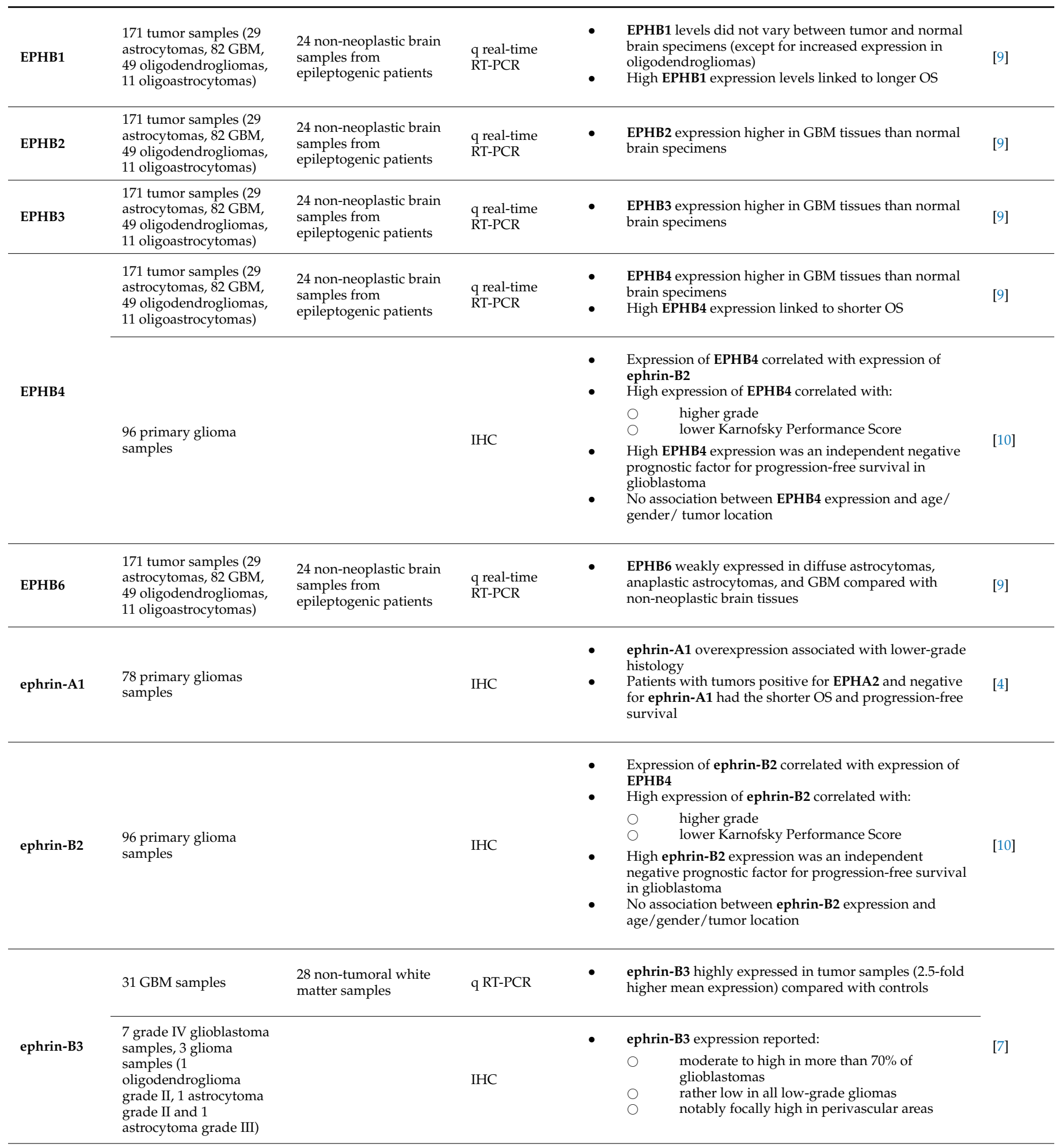


Table 1. Cont.

\section{SALIVARY GLANDS}

$\begin{array}{lll} & & \text { IHC } \\ 49 \text { ACC samples } & \text { 10 normal salivary } & \text { Western blot } \\ \text { gland samples } & \text { real-time } \\ & \text { RT-PCR }\end{array}$

EPHA2
IHC

RT-PCR
- $\quad$ EPHA2 expression higher in ACC tissues

- EPHA2 expression correlated with MVD

- EPHA2 expression and MVD correlated with:

$\begin{array}{ll}\bigcirc & \text { TNM stage } \\ \bigcirc & \text { perineural invasion } \\ \text { perivascular invasion }\end{array}$

- $\quad$ EPHA2 expression and MVD greater in solid type ACC than in cribriform and tubular types

- $\quad$ Aberrant expression of EPHA2 reported. (EPHA2 suspected to play a part in EMT, as the tumor had mesenchymal IHC features)

- ephrin-A1 expression higher in ACC tissue

- $\quad$ ephrin-A1 expression correlated with MVD

- ephrin-A1 expression and MVD correlated with:

IHC

$\begin{array}{ll}\bigcirc & \text { TNM stage } \\ 0 & \text { perineural invasion }\end{array}$

$\bigcirc$ perivascular invasion

- $\quad$ ephrin-A1 expression and MVD greater in solid type ACC than in cribriform and tubular types

ephrin-A1

$\begin{array}{lll}49 \text { primary ACC } & \begin{array}{l}10 \text { normal salivary } \\ \text { gland samples }\end{array} & \begin{array}{l}\text { Western blot } \\ \text { real-time } \\ \text { samples }\end{array} \\ & \text { RT-PCR }\end{array}$

IHC RT-PCR
- $\quad$ No expression of ephrin-A1 reported

THYROID

\begin{tabular}{|c|c|c|c|c|c|}
\hline \multirow[t]{2}{*}{ EPHA2 } & $\begin{array}{l}59 \text { thyroid carcinoma } \\
\text { samples ( } 47 \text { papillary, } 5 \\
\text { follicular, } 5 \text { medullary, } 2 \\
\text { anaplastic) }\end{array}$ & $\begin{array}{l}72 \text { benign tissue } \\
\text { samples }(61 \\
\text { hyperplastic nodules, } 11 \\
\text { Hashimoto thyroiditis } \\
\text { samples) }\end{array}$ & IHC & $\begin{array}{l}\text { - } \quad \text { EPHA2 overexpressed in malignant tissues compared } \\
\text { with benign ones } \\
\text { EPHA2 expression not associated with TNM stage or } \\
\text { capsular/vascular/lymphatic invasion }\end{array}$ & [13] \\
\hline & $\begin{array}{l}74 \text { thyroid carcinoma } \\
\text { samples ( } 68 \text { papillary, } 6 \\
\text { follicular) }\end{array}$ & $\begin{array}{l}14 \text { follicular adenoma } \\
\text { samples }\end{array}$ & IHC & $\begin{array}{l}\text { - EPHA2 significantly higher in cancer tissues than } \\
\text { normal ones }\end{array}$ & [14] \\
\hline EPHA4 & $\begin{array}{l}59 \text { thyroid carcinoma } \\
\text { samples ( } 47 \text { papillary, } 5 \\
\text { follicular, } 5 \text { medullary, } 2 \\
\text { anaplastic) }\end{array}$ & $\begin{array}{l}72 \text { benign tissue } \\
\text { samples ( } 61 \\
\text { hyperplastic nodules, } 11 \\
\text { hashimoto thyroiditis } \\
\text { samples) }\end{array}$ & IHC & $\begin{array}{l}\text { - } \quad \text { EPHA4 expression not differentiated between } \\
\text { malignant and benign cases } \\
\text { Papillary carcinoma showed increased EPHA4 } \\
\text { expression compared with hyperplastic nodules } \\
\text { EPHA4 expression not associated with TNM stage or } \\
\text { capsular/vascular/lymphatic invasion }\end{array}$ & [13] \\
\hline \multirow{2}{*}{ ЕРНB4 } & $\begin{array}{l}56 \text { thyroid carcinoma } \\
\text { samples ( } 46 \text { papillary, } \\
10 \text { follicular) }\end{array}$ & $\begin{array}{l}71 \text { benign thyroid } \\
\text { tissues ( } 56 \text { hyperplastic } \\
\text { nodules, } 12 \text { hashimoto } \\
\text { thyroiditis tissues) }\end{array}$ & $\mathrm{IHC}$ & $\begin{array}{l}\text { - EPHB4 overexpressed in malignant compared with } \\
\text { benign tissues } \\
\text { EPHB4 expression provided a distinct discrimination } \\
\text { between papillary carcinoma and hyperplastic nodules } \\
\text { - } \quad \text { In malignant tumors, EPHB4 overexpression associated } \\
\text { with tumor size }\end{array}$ & [15] \\
\hline & $\begin{array}{l}21 \text { papillary carcinoma } \\
\text { samples }\end{array}$ & $\begin{array}{l}\text { surrounding normal } \\
\text { thyroid samples }\end{array}$ & $\begin{array}{l}\text { cDNA } \\
\text { microarray } \\
\text { Western blot } \\
\text { IHC }\end{array}$ & $\begin{array}{l}\text { EPHB4 overexpression reported in tumor vs normal } \\
\text { tissues } \\
\text { EPHB4 overexpression associated with presence of LN } \\
\text { metastasis }\end{array}$ & [16] \\
\hline ЕРHB6 & $\begin{array}{l}56 \text { thyroid carcinoma } \\
\text { samples ( } 46 \text { papillary, } \\
10 \text { follicular) }\end{array}$ & $\begin{array}{l}71 \text { benign thyroid } \\
\text { samples }(56 \\
\text { hyperplastic nodules, } 12 \\
\text { hashimoto thyroiditis } \\
\text { samples) }\end{array}$ & $\mathrm{IHC}$ & $\begin{array}{l}\text { - } \\
\text { bPHB6 overexpressed in malignant compared to } \\
\text { benign tissues } \\
\text { EPHB6 expression provided a distinct discrimination } \\
\text { between papillary carcinoma and hyperplastic nodules } \\
\text { EPHB6 overexpression associated with tumor size, } \\
\text { positive LNs, capsular/vascular/lymphatic invasion } \\
\text { and recurrence rate }\end{array}$ & [15] \\
\hline
\end{tabular}


Table 1. Cont.

\begin{tabular}{lllll}
\hline & $\begin{array}{l}21 \text { papillary carcinoma } \\
\text { samples }\end{array}$ & $\begin{array}{l}\text { surrounding normal } \\
\text { thyroid samples }\end{array}$ & $\begin{array}{l}\text { cDNA } \\
\text { microarray } \\
\text { Western blot } \\
\text { IHC }\end{array}$ & $\begin{array}{l}\text { ephrin-B2 overexpression reported in tumor vs normal } \\
\text { tissues } \\
\text { ephrin-B2 overexpression associated with presence of } \\
\text { LN metastasis }\end{array}$ \\
\cline { 2 - 6 } ephrin-B2 & $\begin{array}{l}\text { 66 malignant thyroid } \\
\text { samples (23 follicular } \\
\text { carcinomas, 18 follicular } \\
\text { variant of papillary } \\
\text { carcinomas, 25 papillary } \\
\text { carcinomas) }\end{array}$ & $\begin{array}{l}\text { 4 normal thyroid } \\
\text { samples, 26 } \\
\text { hyperplastic nodules, 27 } \\
\text { follicular adenomas }\end{array}$ & $\begin{array}{l}\text { q real-time } \\
\text { PCR }\end{array}$ & $\begin{array}{l}\text { ephrin-B2 mRNA expression elevated in higher TNM stage } \\
\text { neoplasms }\end{array}$ \\
[17]
\end{tabular}

IHC: immunohistochemistry, RT-PCR: reverse transcription-polymerase chain reaction, q RT-PCR: quantitative reverse transcriptionpolymerase chain reaction, OS: overall survival, GBM: glioblastoma multiforme, MVD: microvessel density, ACC: adenoid cystic carcinoma, EMT: epithelial-mesenchymal transition, cDNA: complementary DNA, LN: lymph nodes.

\section{Thoracic and Skin Tumors}

\subsection{Lung}

The role of EPH/ephrin system in lung carcinogenesis has been extensively studied in a number of works that incorporated a large numbers of specimens.

\subsubsection{EPHAs}

EPHA1 overexpression was associated with high tumor proliferative capacity, assessed by the Ki67 index, probably revealing a link between its upregulation with more aggressive tumor phenotypes [20]. Intriguingly, EPHA2, largely reported for its negative impact on many solid tumors' pathogenesis, seems to play a beneficial role in lung carcinogenesis. Two studies, which jointly included 420 patients with stage I Non-Small-Cell Lung Carcinoma (NSCLC), suggested that high EPHA2 expression was correlated with well-differentiated tumors, reduced smoking status, adenocarcinoma histological type, stage IA tumors, as well as the presence of Epidermal Growth Factor Receptor (EGFR) gene mutations. Both groups of researchers indicated EPHA1 as a positive prognostic factor for NSCLC patients [21,22]. EPHA4, EPHA5, and EPHA7 also exert a positive influence on lung cancer tumorigenesis. In the aforementioned study by Giaginis et al, EPHA4 was associated with low tumor stage, decreased presence of inflammation, and favorable OS. Additionally, EPHA5 overexpression was correlated with tumor proliferative capacity and longer OS and EPHA7 overexpression correlated with tumor proliferative capacity and older age, presence of fibrosis, as well as with smaller tumor size [20].

\subsubsection{EPHBs}

EPHs of the B subgroup appear to overwhelmingly contribute to lung cancer tumorigenesis. EPHB1 expression, measured through IHC and Western blot in 60 NSCLC specimens, was higher in cancer tissues compared with non-neoplastic ones. Additionally, EPHB1 expression was higher in patients with metastatic disease and shorter OS [23]. EPHB2 exhibited elevated expression in cancer NSCLC tissues, being correlated with increased depth of invasion, higher TNM stage, and decreased patient OS [24]. EPHB4 overexpression was linked to low tumor differentiation, high Ki67 index, and presence of LN metastasis in a series of 93 lung adenocarcinoma tissues [25].

As far as ephrins are concerned, few data currently exist linking their action to lung carcinogenesis. Ephrin-A1 was reported to have no impact on clinical outcome in two studies $[21,26]$, while a third study associated its overexpression with reduced smoking status, adenocarcinoma histological type, high level of tumor differentiation, and the presence of EGFR gene mutations, attributing to the ligand a positive influence in tumorigenesis [22]. Ephrin-B2 expression was absent in all 93 lung adenocarcinoma tissues in the aforementioned study [25], and ephrin-B3 expression, while observed as higher in non-squamous tumors, exhibited no effect on patient OS [21]. Table 2 and Figure 3 include information regarding the clinical impact of EPH/ephrin expression in lung cancer. 


\subsection{Breast}

The established, immense impact of breast tumors' molecular signature in disease prognosis and treatment regimens has shifted the focus of the scientific community on those molecular mechanisms implicated in the disease pathogenesis and the search for novel biomarkers that influence the clinical outcome. Among them, the expression and effect of the EPH/ephrin system in breast cancer tumorigenesis has been extensively studied, with overexpression of all members contributing to worse disease prognosis [27-34].

\subsubsection{EPHAs}

EPHA2 expression has been reported as higher in cancer tissues compared with noncancerous epithelium, elevated EPHA2 expression being associated with reduced OS, while EPHA2 and ephrin-A1 co-expression are correlated with recurrence rates [28]. EPHA4 overexpression was also associated with malignancy and cases with reduced OS [28]. In addition, data mining from the GOBO and ONCOMINE databases indicated that elevated EPHA4 $m R N A$ expression correlated with stage 3 and 4 tumors, poor tumor differentiation, shortened relapse-free survival, positive LN status, and the highly aggressive basal-like subtype [29]. EPHA7 exhibited higher expression in cancer tissues compared with normal ones and in samples from patients with reduced OS as well [28], while EPHA8 expression exhibited no significant increase in cancerous tissues compared with normal ones and did not affect clinical outcomes [28].

\subsubsection{EPHBs}

EPHB1 expression showed no correlation with clinical parameters [30]. On the other hand, the varying impact of EPHB2 expression in breast cancer patients' clinical outcomes reflects the complex role of EPH/ephrin molecular mechanisms in tumorigenesis. EPHB2 exhibited both membranous and cytoplasmic staining in IHC, showing an inverse correlation between the two patterns. Cytoplasmic expression of EPHB2 negatively affected patients' outcomes, as it was positively associated with shorter OS, histological grade, and HER2 expression. On the contrary, membranous EPHB2 staining was correlated with longer patient OS [27]. Other studies yielded contradictory results regarding the influence of EPHB2 expression in breast cancer pathogenesis, with Wu et al linking its overexpression to decreased OS and DFS [31], and another group of researchers associating it with improved patient prognosis [30]. Mu et al associated elevated mRNA EPHB3 expression with worse OS and EPHB4 mRNA overexpression with improved RFS [30]. In contrast, other studies underlined that EPHB4 overexpression is correlated with malignancy and reduced OS [28], higher histological grade and stage [31], as well as with shorter metastasis-free survival [32]. Despite its beneficial influence in many neoplastic diseases, EPHB6 seems to promote tumorigenesis in the breast, as its expression was reported as higher in malignant tissues and was correlated with reduced OS [28].

\subsubsection{Ephrins}

Ephrin-A1 and EPHA2 co-expression is associated with recurrence [27]. Similarly, ephrin-B2 expression is associated with the clinically aggressive basal-like breast cancer subtype and HER2(+) tumors [33], while its overexpression is associated with the presence of LN metastasis, HER2 positivity, and the triple-negative breast cancer subtype [34]. On the other hand, the protective role of ephrin-B2 was underlined through the association of its expression with high estrogen receptor expression, low HER2 expression, low histological grade, and good patient' prognosis [32].

All information retrieved on the clinical impact EPH/ephrin system expression is presented in Table 2 and Figure 3.

\subsection{Skin}

EPHA1 expression in 56 basal cell and 32 squamous cell carcinoma was examined through IHC and q RT-PCR and compared to 10 normal skin tissues. Cancer tissues exhib- 
ited downregulation of EPHA1 in relation to normal tissues, and EPHA1 decreased expression associated with increased tumor thickness in squamous cell carcinoma cases [35].

On the other hand, EPHA2 overexpression in melanoma tissues was correlated with increased melanoma thickness and increased tumor cell proliferative capacity, assessed as the Ki67 index. In addition, high expression of its ligand, ephrin-A1, was also correlated with increased melanoma thickness, as well as decreased patient survival [36].

Data from the two studies on EPH/ephrins and skin cancer are presented in Table 2 and Figure 3.

Table 2. EPHs/ephrins (bold) studied in solid tumors of lung, breast, and skin and correlations with clinicopathological parameters.

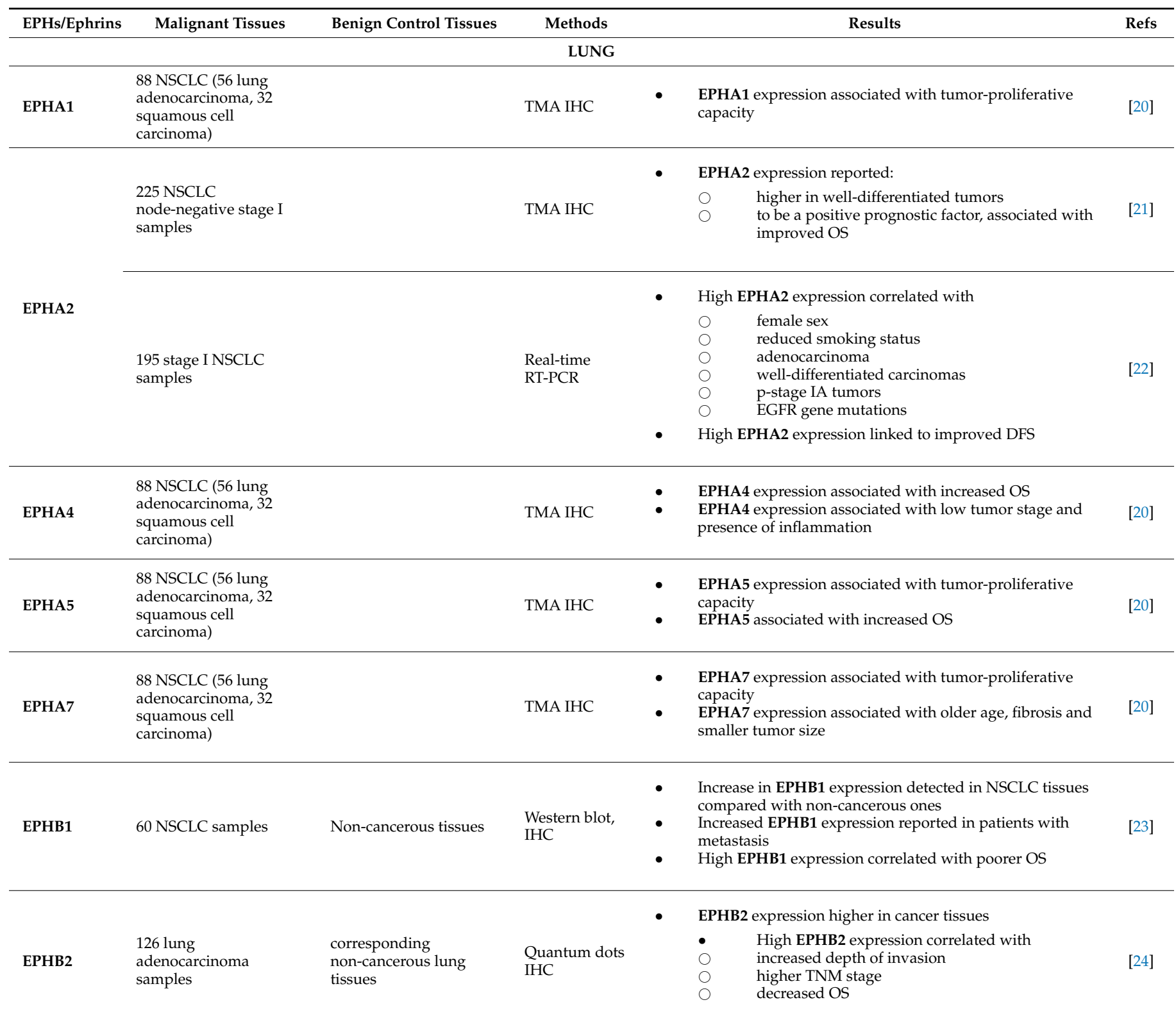

- $\quad$ EPHB4 differentially expressed in lung adenocarcinoma

- $\quad$ EPHB4 expression linked to

EPHB4 93 lung adenocarcinoma samples
IHC $\begin{array}{ll}\bigcirc & \text { low tumor differentiation } \\ \bigcirc & \text { high Ki67 expression } \\ & \text { LN metastasis }\end{array}$

- No correlation between EPHB4 expression and sex, age, or ALK mutation 
Table 2. Cont.

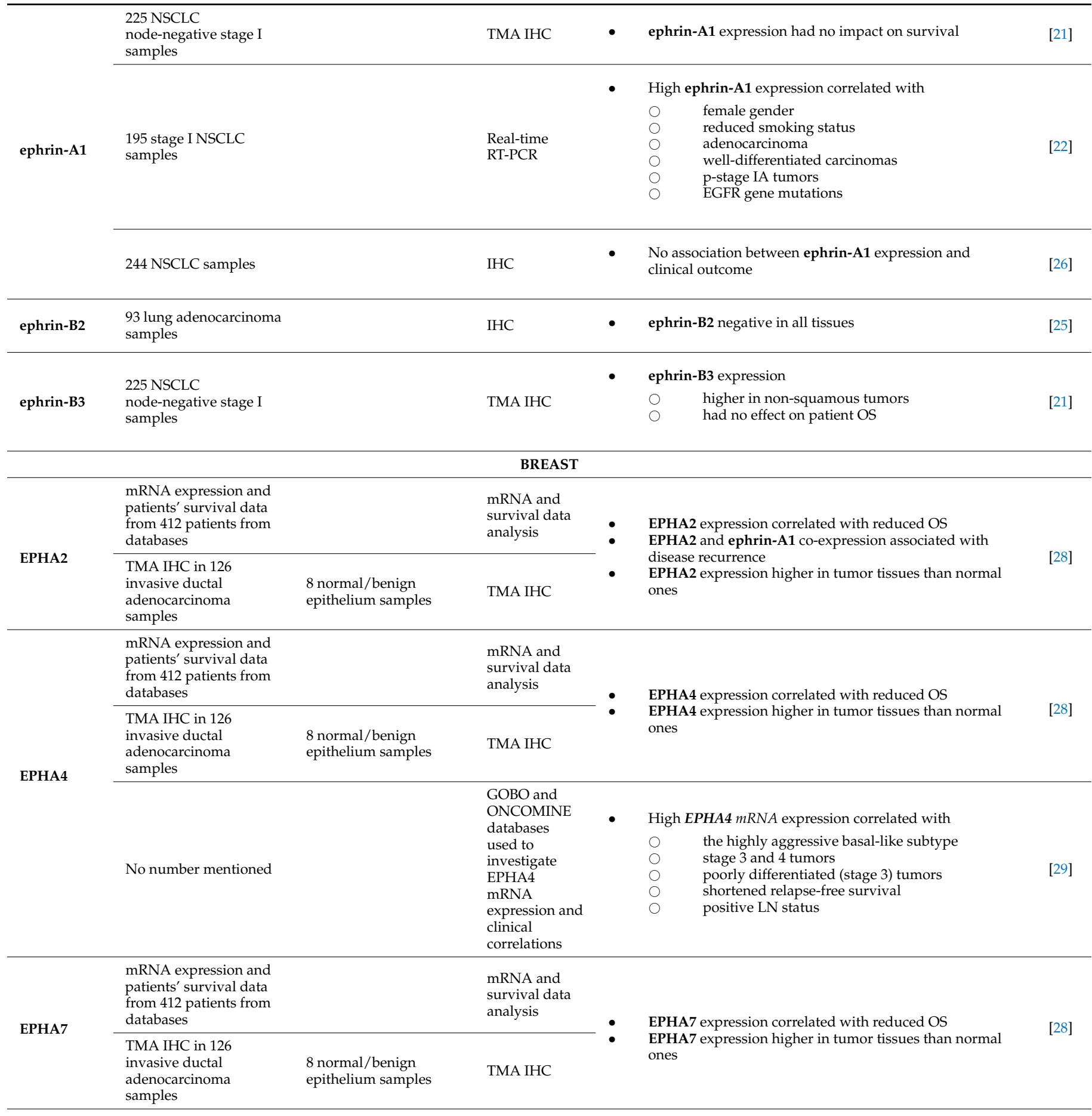


Table 2. Cont.

\begin{tabular}{|c|c|c|c|c|c|}
\hline \multirow{2}{*}{ EPHA8 } & \multicolumn{2}{|l|}{$\begin{array}{l}\text { mRNA expression and } \\
\text { patients' survival data } \\
\text { from } 412 \text { patients from } \\
\text { databases }\end{array}$} & \multirow[t]{2}{*}{$\begin{array}{l}\text { mRNA and } \\
\text { survival data } \\
\text { analysis }\end{array}$} & \multirow{2}{*}{ - $\quad$ EPHA8 not associated with clinical outcome } & \multirow{2}{*}{ [28] } \\
\hline & $\begin{array}{l}\text { TMA IHC in } 126 \\
\text { invasive ductal } \\
\text { adenocarcinoma } \\
\text { samples }\end{array}$ & $\begin{array}{l}8 \text { normal/benign } \\
\text { epithelium samples }\end{array}$ & & & \\
\hline EPHB1 & $\begin{array}{l}3554 \text { breast cancer } \\
\text { samples }\end{array}$ & & $\begin{array}{l}m R N A \\
\text { expression } \\
\text { data and } \\
\text { survival } \\
\text { information } \\
\text { from the KM } \\
\text { plotter } \\
\text { database }\end{array}$ & $\begin{array}{l}\text { - High } m R N A \text { expression of all EPHs studies associated with } \\
\text { increased risk of mortality for LN }(+) \text { patients } \\
\text { EPHB1 expression not associated with OS }\end{array}$ & [30] \\
\hline \multirow{4}{*}{ ЕРНB2 } & $\begin{array}{l}\text { Cohort } 1 \text { : } \\
65 \text { LN positive breast } \\
\text { cancer samples }\end{array}$ & & RT-PCR & \multirow{2}{*}{$\begin{array}{l}\text { Inverse correlation between membranous and } \\
\text { cytoplasmic EPHB2 expression } \\
\text { Membranous EPHB2 expression correlated with longer } \\
\text { OS, while cytoplasmic EPHB2 expression with shorter OS } \\
\text { Cytoplasmic EPHB2 expression positively correlated } \\
\text { with histological grade and HER2 expression }\end{array}$} & \multirow{2}{*}{ [27] } \\
\hline & $\begin{array}{l}\text { Cohort } 2 \text { : } \\
216 \text { breast cancer } \\
\text { samples }\end{array}$ & & IHC & & \\
\hline & $\begin{array}{l}3554 \text { breast cancer } \\
\text { samples }\end{array}$ & & $\begin{array}{l}\text { mRNA } \\
\text { expression } \\
\text { data and } \\
\text { survival } \\
\text { information } \\
\text { from the KM } \\
\text { plotter } \\
\text { database }\end{array}$ & $\begin{array}{l}\text { - High } m R N A \text { expression of EPHB2 associated with } \\
\text { improved OS } \\
\text { - } \quad \text { High } m R N A \text { expression of all EPHs studied associated } \\
\text { with increased risk of mortality for LN (+) patients }\end{array}$ & [30] \\
\hline & $\begin{array}{l}94 \text { breast carcinoma } \\
\text { samples }\end{array}$ & $\begin{array}{l}9 \text { normal breast tissue } \\
\text { samples }\end{array}$ & $\begin{array}{l}\text { IHC } \\
\text { Semi- } \\
\text { quantitative } \\
\text { RT-PCR }\end{array}$ & $\begin{array}{l}\text { Increased EPHB2 expression negatively associated with } \\
\text { OS and DFS }\end{array}$ & [31] \\
\hline ЕРНB3 & $\begin{array}{l}3554 \text { breast cancer } \\
\text { samples }\end{array}$ & & $\begin{array}{l}m R N A \\
\text { expression } \\
\text { data and } \\
\text { survival } \\
\text { information } \\
\text { from the KM } \\
\text { plotter } \\
\text { database }\end{array}$ & $\begin{array}{l}\text { - } \quad \text { High mRNA expression of EPHB3 associated with worse } \\
\text { OS } \\
\text { High mRNA expression of all EPHs studies associated } \\
\text { with increased risk of mortality for LN }(+) \text { patients }\end{array}$ & [30] \\
\hline \multirow{5}{*}{ ЕРНВ4 } & $\begin{array}{l}\text { mRNA expression and } \\
\text { patients' survival data } \\
\text { from } 412 \text { patients from } \\
\text { databases }\end{array}$ & & $\begin{array}{l}\text { mRNA and } \\
\text { survival data } \\
\text { analysis }\end{array}$ & \multirow{2}{*}{$\begin{array}{l}\text { EPHB4 expression correlated with reduced OS } \\
\text { EPHB4 expression higher in tumor tissues than normal } \\
\text { ones }\end{array}$} & \multirow{2}{*}{ [28] } \\
\hline & $\begin{array}{l}\text { TMA IHC in } 126 \\
\text { invasive ductal } \\
\text { adenocarcinoma } \\
\text { samples }\end{array}$ & $\begin{array}{l}8 \text { normal/benign } \\
\text { epithelium samples }\end{array}$ & TMA IHC & & \\
\hline & $\begin{array}{l}3554 \text { breast cancer } \\
\text { samples }\end{array}$ & & $\begin{array}{l}\text { mRNA } \\
\text { expression } \\
\text { data and } \\
\text { survival } \\
\text { information } \\
\text { from the KM } \\
\text { plotter } \\
\text { database }\end{array}$ & $\begin{array}{l}\text { - High mRNA expression of EPHB4 associated with } \\
\text { improved OS } \\
\text { - High mRNA expression of all EPHs studied associated } \\
\text { with increased risk of mortality for LN }(+) \text { patients }\end{array}$ & [30] \\
\hline & $\begin{array}{l}94 \text { breast carcinoma } \\
\text { samples }\end{array}$ & $\begin{array}{l}9 \text { normal breast tissue } \\
\text { samples }\end{array}$ & $\begin{array}{l}\text { IHC } \\
\text { Semi- } \\
\text { quantitative } \\
\text { RT-PCR }\end{array}$ & $\begin{array}{l}\text { EPHB4 expression associated with higher histological } \\
\text { grade and stage }\end{array}$ & [31] \\
\hline & $\begin{array}{l}216 \text { breast cancer } \\
\text { samples }\end{array}$ & & IHC & $\begin{array}{l}\text { - High EPHB4 expression associated with shorter } \\
\text { metastasis-free survival }\end{array}$ & [32] \\
\hline
\end{tabular}


Table 2. Cont.

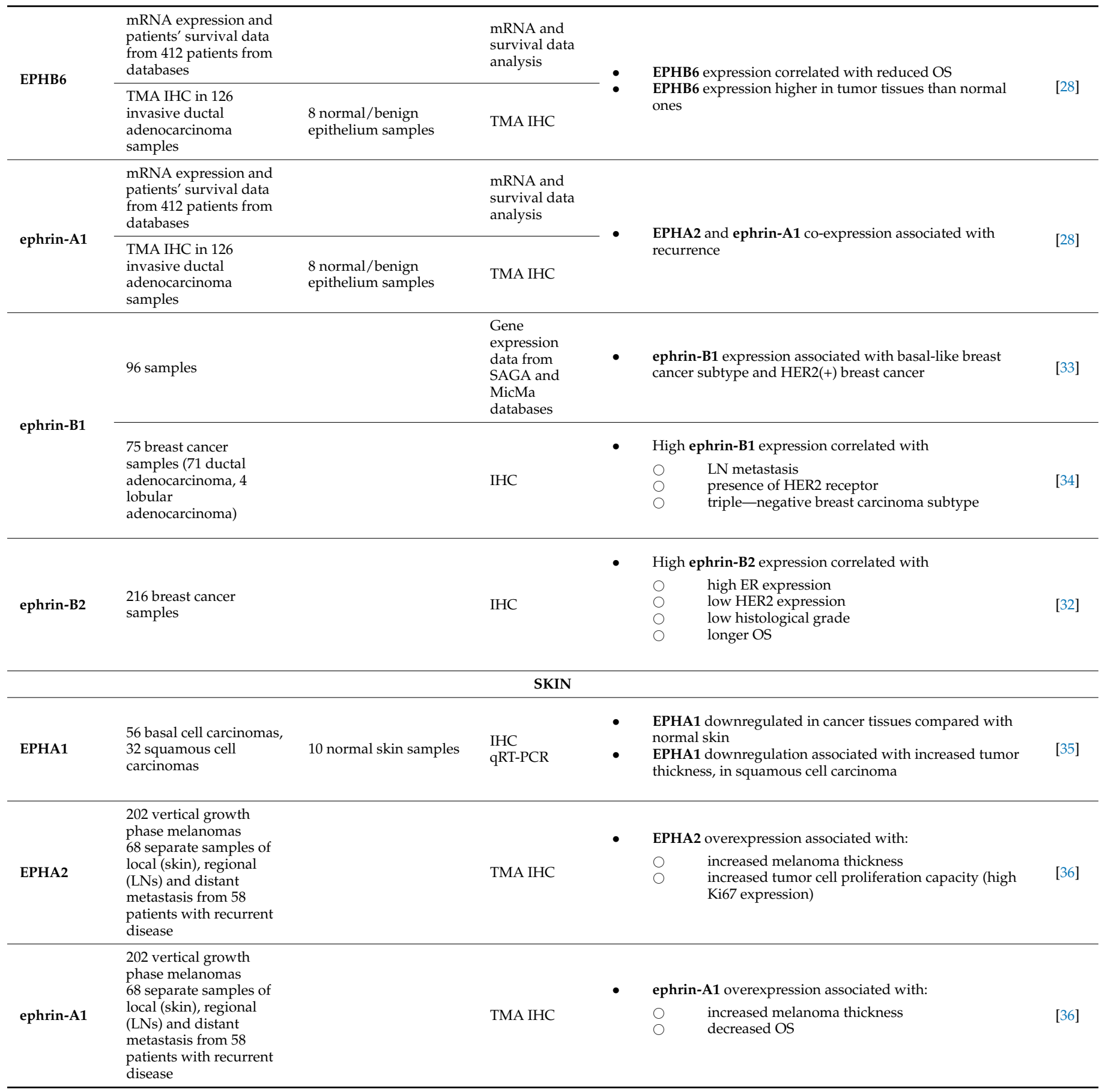

NSCLC: non-small cell lung carcinoma, TMA: tissue microarrays, IHC: immunohistochemistry, LN: lymph nodes, RT-PCR: reverse transcription-polymerase chain reaction, EGFR: epidermal growth factor receptor, DFS: disease-free survival, ALK: anaplastic lymphoma kinase, OS: overall survival.

\section{Gastrointestinal Tract Neoplasia}

\subsection{Esophagus}

A limited amount of information exists concerning the clinical impact of the EPH/ephrin system expression in esophageal carcinomas. Schauer et al investigated the expression of EPHB3 and E-cadherin in healthy esophagi and Barrett's carcinoma patients, reporting that both were reduced in adenocarcinoma tissues compared with normal or dysplastic ones [37]. Simultaneous expression of the two proteins showed an inverse correlation with tumor stage. Interestingly, when EPHB3 was expressed, redistribution of E-cadherin from the cytoplasm to 
the membrane was observed, revealing a possible mechanism through which EPHB3 might exert its speculated protective role, as E-cadherin membranous expression stabilizes cell to cell adhesion, decreasing tumor cells' invasion capabilities, and disrupts EMT transition and cell proliferation. Other studies reported that EPHB4 was gradually overexpressed, from preneoplastic lesions to gastroesophageal cancers, and was correlated positively with advanced tumor stage. On the other hand, EPHB6 expression was down-regulated in neoplastic tissues, in accordance with its tumor-suppressive properties observed in other cancers [38]. Information concerning the clinical impact of the EPH/ephrin system expression in esophageal cancers is summarized in Table 3 and Figure 4.

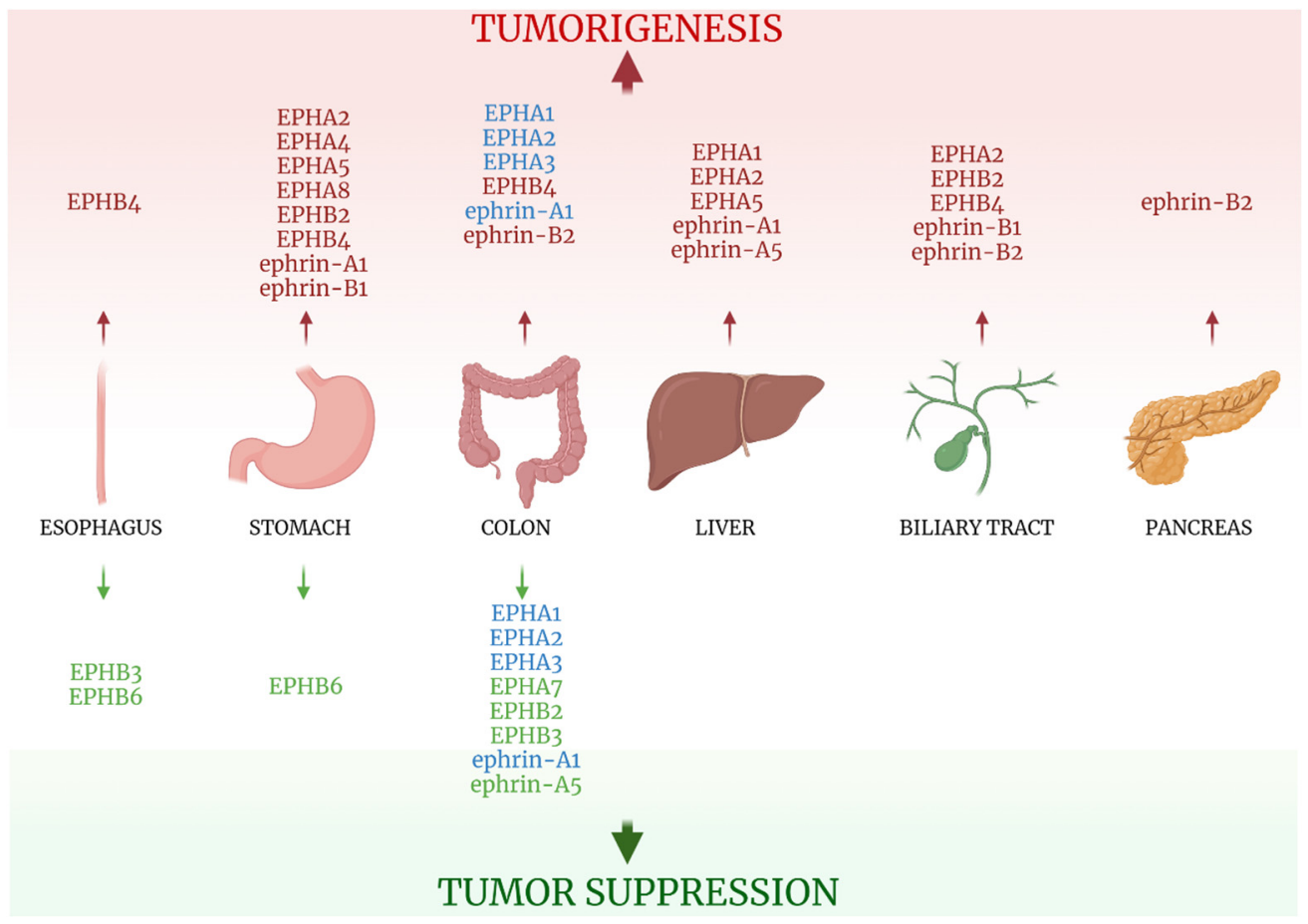

Figure 4. EPH/ephrin family role in solid tumors of organs of the gastrointestinal tract, liver, biliary tract, and pancreas. Red-colored EPHs/ephrins enhance tumorigenesis, while green-colored ones suppress it. It is unclear if EPHA1, EPHA2, EPHA3, and ephrin-A5 enhance tumorigenesis or tumor suppression (blue font). See text and Table 3. Created with BioRender.com (accessed on 2 August 2021).

\subsection{Stomach}

\subsubsection{EPHAs/Ephrin-As}

The clinical impact of EPH/ephrin member proteins' expression in gastric cancer is among the most extensively studied. Most researchers utilized a variety of methods, such as IHC, western blot, or RT-PCR, to assess EPH/ephrin protein or mRNA expression and proceeded to correlate it with clinicopathological parameters.

Yuan et al [39] studied the expression of EPHA2 and ephrin-A1 in 176 gastric adenocarcinoma specimens, underlining that they were significantly overexpressed in cancer tissues when compared with normal ones. Expression of both proteins was correlated with increased TNM stage and LN metastasis rate, with EPHA2 overexpression also linked to deeper levels of tumor invasion and found to be an independent poor prognostic factor, as its increased expression correlated with decreased OS. Nakama et al, however, observed that while EPHA2/ephrin-A1 genes expression was associated with tumors that invaded in deeper layers of the stomach and had undefined borders or infiltrated diffusely, no correlation existed regarding the tumor size, patients' age, vessel infiltration, and lymph node status [40]. On the contrary, in a large study that included 91 gastric adenocarcinoma samples, high EPHA2 protein expression was associated with advanced tumor stage, size, LN metastasis, TNM stage, and lymphovascular invasion [41]. 
EPHA4 and EPHA8 also seem to hold tumorigenic properties. Both proteins' expression was linked to depth of malignant infiltration of the stomach and lower OS [42,43], with high EPHA8 expression additionally accompanied by lower tumor differentiation, as well as higher TNM stages and distant metastasis rate.

Interestingly, overexpression of a number of EPHs, belonging in A and B subgroups, was also observed in gastric stromal cells associated with gastric adenocarcinoma [44]. Such results possibly prove that EPHs exert their carcinogenic properties through their involvement in cell adhesion and matrix-cell interactions, creating a direct clinical impact. Ephrin ligands expressed on tumor cells could possibly help them interact with stromal cells expressing EPHs, promoting carcinogenic properties such as increased cell motility that would enhance tissue infiltration or triggering molecular cascades that promote cell proliferation. The EPH/ephrin system may represent a key factor in the creation of a tumor-promoting microenvironment, and further study regarding their expression in non-tumorous tissues surrounding cancer cells is called for.

\subsubsection{EPHBs/Ephrin-Bs}

EPHs of the B subgroup and their ligands also seem to play a role in gastric cancer pathogenesis. Ephrin-B1 expression was positively correlated with the tumor differentiation level [45]. EPHB4 expression, that was reported higher in Barrett esophagus, was also recorded elevated in gastroesophageal carcinomas, tumors of higher stage and in malignant cells at the tumor invasion front [38]. On the other hand, two studies underline the protective role of EPHB6, as its expression was found to be downregulated in tumor cells [38], being negatively associated with tumor stage, LN metastasis, and a poor level of differentiation [46].

Lastly, ephrin-B1 expression was reported more frequent in poorly differentiated adenocarcinomas than well-differentiated ones [45].

Data from research on EPH/ephrin expression and clinicopathological features in gastric cancer are presented in Table 3 and Figure 4.

\subsection{Colon}

Colorectal cancer (CRC) is the third most common malignancy in the world and the third leading cause of cancer-related deaths [47]. The heavy clinical impact of the disease has led to extensive research on its pathogenesis, including the tumorigenic role of the $\mathrm{EPH} /$ ephrin system. Strikingly, many EPHs and their ligands seem to have a protective function [48-60].

\subsubsection{EPHAs}

EPHA1, although increased in CRC tissues compared with normal ones, exhibited decreased expression in advanced TNM disease stages [48,49], with one study correlating its low expression to poor OS [49]. Similarly, EPHA2 was found to be upregulated in CRC tissues compared with their non-cancerous counterparts, but its downregulation was prevalent in more advanced disease stages $[48,50]$. Moreover, EPHA2 overexpression was observed in tumors less than 5 centimeters in diameter compared with larger ones [50]. EPHA3 and EPHA7 exhibited loss of expression in $96 \%$ of the cases in one of the three previous studies [48]. On the contrary, Li et al [51] reported that EPHA3 not only was overexpressed in CRC tissues compared with adjacent normal mucosa, but was also positively linked to patients' age, poor differentiation level of the tumor, and LN metastasis.

\subsubsection{EPHBs}

The inhibitory role of EPHB2 in colon carcinogenesis is among the ones most thoroughly studied. Multiple works have investigated its clinical impact, associating its high expression levels with lower tumor stage [54,57], lower histological grade [58], higher grade of histological differentiation [54], low LN metastasis rate [57], longer OS and DFS [54,56,57], and lower recurrence and death rates [55]. In a large series of tissue spec- 
imens from CRC patients, scientists have demonstrated that from normal colon mucosa to preneoplastic lesions, to malignant tissues, to the tumor invasion front, to metastasis, EPHB4 expression is progressively reduced $[54,57,58]$.

Jan et al examined the expression of EPHB3 in a total of 642 specimens, reporting its attenuation during transition from adenoma to carcinoma and its further decline as the tumor invaded into deeper tissues. Statistical analysis linked EPHB3 expression to tumor differentiation, lymphovascular invasion, TNM stage, microsatellite instability and better OS [59].

In contrast, EPHB4 was presented in one study as being among the few members of the EPH/ephrin family that favor tumorigenesis. While its expression was minimal to absent in normal colon tissues, it was strongly expressed in CRC and associated with tumor depth of invasion, presence of LN and distant metastasis and TNM stage [60].

\subsubsection{Ephrins}

Ephrin-A1 expression, although higher in CRC tissues compared with normal ones [48,50], was correlated to early-stage cancers and smaller tumor size [50]. Ephrin-A5 expression, albeit found higher than its EPHA receptors [48], was significantly reduced in colon cancer tissues and was negatively associated with tumor differentiation and clinical stage [52]. Ephrin-B2 expression, contrary to the seemingly tumor suppressive properties of ephrin-A5, was found elevated in CRC samples, with frequent enhancement on the luminal surface of carcinoma epithelium [53]. All information on EPH/ephrin expression on CRC tissues is summarized in Table 3 and Figure 4.

\subsection{Liver}

All of the EPH/ephrins investigated in Hepatocellular Carcinoma (HCC), with the only exception of ephrin-A5, seem to have a negative impact on carcinogenesis and patients clinical outcomes. Ephrin-A1 expression was reported as lowest in normal liver tissues, elevated in cirrhotic liver specimens, and further enhanced in HCC [61,62]. Its expression was correlated with Alpha Fetoprotein expression, which was associated with poor OS [61]. Wada et al also linked ephrin-A1 expression to poorer patients' prognosis [63]. EPHA1 exhibited strong expression in HCC specimens [61], and EPHA2 expression was associated with decreased differentiation and shorter OS [62], as well as with microscopic portal invasion. A study that examined the expression of three kinases (Anaplastic Lymphoma Kinase, Fibroblast Growth Factor Receptor 2, and EPHA5) in a series that included 250 HCC cases, underlined that coactivation of all three of them led to a worse prognosis [64]. On the contrary, Wang et al [65] examined the mRNA expression of the two alternative isoforms of ephrin-A5, large ephrin-A5 (ephrin-A5L), and small ephrin-A5 (ephrin-A5S), through means of quantitative real-time PCR, reporting them lower in HCC compared with peritumoral tissues. Ephrin-A5S expression positively correlated with old age and histological grade, and its expression in peritumoral tissues was associated with better DFS and OS. Data are presented in Table 3 and Figure 4.

\subsection{Biliary Tract}

Limited data is currently available regarding the role of EPHs and their ligands in biliary tract neoplasia and its clinical significance. Sheng et al observed that the EPHA2 gene was frequently mutated in primary intrahepatic cholangiocarcinoma (ICC) tumors, with mutations even more likely to occur in cases with lymph node metastasis [66]. Another study included 50 ICC patients to examine EPHB2, EPHB4, ephrin-B1, and ephrin-B2 expression, as well as tumors' MVD through CD34 IHC staining [67]. An association between metastasis status and EPHB2 expression, EPHB2/ephrin-B1 co-expression, EPHB2/ephrinB2 co-expression, EPHB4 expression along with high MVD and lastly ephrin-B2 expression and high MVD, was reported.

Information regarding the $\mathrm{EPH} /$ ephrin system's role in biliary tract neoplasia is summarized on Table 3 and Figure 4. 


\subsection{Pancreas}

The only study examining the clinical significance of EPHs/ephrins members expression in pancreatic cancer is the one conducted by Zhu et al [68] and concerned the ephrin-B2 gene expression in pancreatic ductal adenocarcinoma (PDAC). The researchers gathered information on ephrin-B2 mRNA expression from 179 PDAC patients and 171 normal pancreatic tissues. Statistical analysis showed that ephrin-B2 expression was higher in PDAC tissues when compared with normal ones and correlated with shorter OS and DFS. Furthermore, samples from 54 PDAC tissues and adjacent uninvolved tissues were tested for ephrin-B2 expression through IHC, western blot, and q real-time PCR analysis. Ephrin-B2 expression was again reported higher in cancerous tissues, and its overexpression was linked to tumor TNM stage and high Ki67 expression. Table 3 and Figure 4 summarize the study.

Table 3. EPHs/ephrins (bold) studied in solid tumors of the gastrointestinal tract, liver, biliary tract, and pancreas and correlations with clinicopathological parameters.

\begin{tabular}{lllll}
\hline EPHs/Ephrins & Malignant Tissues & $\begin{array}{c}\text { Benign Control } \\
\text { Tissues }\end{array}$ & Methods & RSOPHAGUS \\
\hline EPHB3 & $\begin{array}{l}\text { 141 Barrett's carcinoma } \\
\text { samples }\end{array}$ & $\begin{array}{l}20 \text { healthy } \\
\text { esophagi } \\
\text { samples }\end{array}$ & $\begin{array}{l}\text { IHC } \\
\text { q PCR }\end{array}$ & $\begin{array}{l}\text { EPHB3 and E-cadherin IHC expression was reduced in } \\
\text { adenocarcinoma compared with dysplasia or healthy } \\
\text { esophageal mucosa } \\
\text { Simultaneous expression of E-cadherin and EPHB3 } \\
\text { showed inverse correlation with the tumor stage } \\
\text { E-cadherin mRNA expression reduced in } \\
\text { adenocarcinoma compared with dysplasia }\end{array}$
\end{tabular}

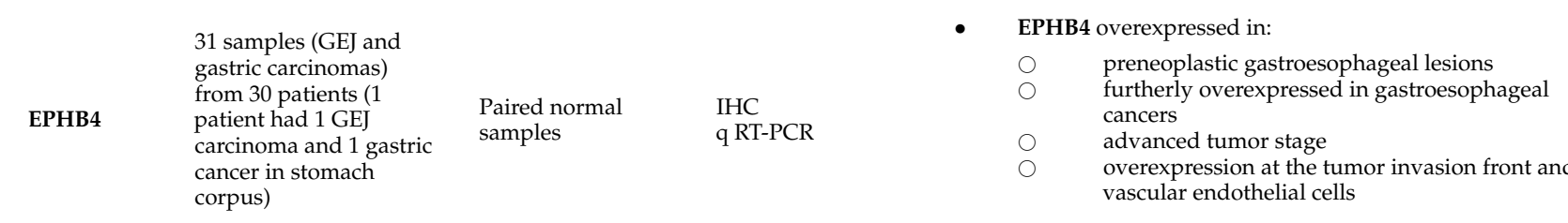

$\begin{array}{ll}\begin{array}{l}\text { cancer in stomach } \\ \text { corpus) }\end{array} & \begin{array}{l}\text { overexpression at the tumor } \\ \text { vascular endothelial cells }\end{array}\end{array}$

\begin{tabular}{llll}
\hline EPHB6 & $\begin{array}{l}31 \text { samples (GEJ and } \\
\text { gastric carcinomas) } \\
\text { from } 30 \text { patients }\end{array}$ & $\begin{array}{l}\text { Paired normal } \\
\text { samples }\end{array}$ & $\begin{array}{l}\text { IHC } \\
\text { q RT-PCR }\end{array}$
\end{tabular}$\quad \begin{aligned} & \text { EPHB6 was down-regulated, consistent with its } \\
& \text { tumor-suppressive properties in other cancers }\end{aligned}$

STOMACH

\begin{tabular}{|c|c|c|c|c|c|c|}
\hline \multirow{4}{*}{ EPHA2 } & $\begin{array}{l}176 \text { gastric } \\
\text { adenocarcinoma } \\
\text { samples }\end{array}$ & $\begin{array}{l}\text { Paired adjacent } \\
\text { normal tissues }\end{array}$ & $\begin{array}{l}\text { Real-time RT-PCR } \\
\text { IHC } \\
\text { Western blot }\end{array}$ & $\begin{array}{l}\text { EPI } \\
\bigcirc \\
\bigcirc \\
\bigcirc \\
\text { EPI } \\
\text { ove }\end{array}$ & $\begin{array}{l}\text { expression correlated with: } \\
\text { depth of tumor invasion } \\
\text { LN metastasis } \\
\text { TNM stage } \\
\text { is an independent poor prognostic factor, and its } \\
\text { oression is linked to poor OS }\end{array}$ & [39] \\
\hline & $\begin{array}{l}46 \text { adenocarcinomas, } 2 \\
\text { adenosquamous } \\
\text { carcinomas, } 1 \\
\text { neuroendocrine } \\
\text { carcinoma }\end{array}$ & $\begin{array}{l}\text { Corresponding } \\
\text { non-tumor samples }\end{array}$ & $\begin{array}{l}\text { Semiquantitative } \\
\text { RT-PCR } \\
\text { IHC } \\
\text { Western blot }\end{array}$ & \multicolumn{2}{|c|}{$\begin{array}{l}\text { EPHA2 expression linked to tumor invasion and tumors } \\
\text { with undefined borders or that infiltrated diffusely } \\
\text { No correlation between EPHA2 expression and tumor } \\
\text { size/age/vessel infiltration/LN metastasis }\end{array}$} & [40] \\
\hline & $\begin{array}{l}91 \text { gastric } \\
\text { adenocarcinomas }\end{array}$ & $\begin{array}{l}7 \text { gastrointestinal } \\
\text { stromal tumor } \\
\text { samples }\end{array}$ & $\begin{array}{l}\text { IHC } \\
\text { Western blot }\end{array}$ & $\begin{array}{l}\text { Hig } \\
\bigcirc \\
\bigcirc \\
\bigcirc \\
\bigcirc \\
\bigcirc\end{array}$ & $\begin{array}{l}\text { PHA2 expression correlated with: } \\
\text { advanced stage } \\
\text { tumor size } \\
\text { LN metastasis } \\
\text { lymphovascular invasion } \\
\text { TNM stage }\end{array}$ & [41] \\
\hline & $\begin{array}{l}107 \text { gastric } \\
\text { adenocarcinoma } \\
\text { samples ( } 54 \text { of them } \\
\text { received adjuvant } \\
\text { chemotherapy) }\end{array}$ & $\begin{array}{l}\text { Normal paired } \\
\text { gastric samples }\end{array}$ & $\begin{array}{l}\text { Proteome analysis } \\
\text { (LC-MS/MS) } \\
\text { mRNA (real-time } \\
\text { RT-PCR) } \\
\text { IHC }\end{array}$ & \multicolumn{2}{|c|}{$\begin{array}{l}\text { EPHA2 expression was 2-fold higher in GCSC than GSC } \\
\text { Cases that showed intermingling of EPHA2 (+) cells and } \\
\text { GCSCs showed }\end{array}$} & [44] \\
\hline
\end{tabular}


Table 3. Cont.

\begin{tabular}{|c|c|c|c|c|c|c|}
\hline EPHA4 & $\begin{array}{l}24 \text { paired fresh gastric } \\
\text { adenocarcinoma } \\
\text { samples, } 74 \text { fresh frozen } \\
\text { paraffin embedded } \\
\text { gastric adenocarcinoma } \\
\text { samples, } 55 \text { gastric } \\
\text { adenocarcinoma } \\
\text { samples in tissue } \\
\text { microarrays }\end{array}$ & $\begin{array}{l}\text { Adjacent } \\
\text { non-tumor samples } \\
\text { from } 24 \text { gastric } \\
\text { adenocarcinoma } \\
\text { specimens }\end{array}$ & $\begin{array}{l}\text { Real-time RT-PCR } \\
\text { RT-PCR } \\
\text { IHC }\end{array}$ & $\begin{array}{ll}\text { - } & \text { Ove } \\
\text { tiss } \\
\text { EPI } \\
0 \\
\text { - } \\
\text { EPr } \\
\text { EPr }\end{array}$ & $\begin{array}{l}\text { pression of EPHA4 in IHC was observed in cancer } \\
\text { protein levels associated with: } \\
\text { depth of invasion } \\
\text { recurrence } \\
\text { (+) cancer tissues showed shorter OS than } \\
\text { (-) cancers }\end{array}$ & [42] \\
\hline EPHA5 & $\begin{array}{l}107 \text { gastric } \\
\text { adenocarcinoma } \\
\text { samples ( } 54 \text { of them } \\
\text { received adjuvant } \\
\text { chemotherapy) }\end{array}$ & $\begin{array}{l}\text { Normal paired } \\
\text { gastric samples }\end{array}$ & $\begin{array}{l}\text { Proteome analysis } \\
\text { (LC-MS/MS) } \\
\text { mRNA (real-time } \\
\text { RT-PCR) } \\
\text { IHC }\end{array}$ & - $\quad \mathrm{EPH}$ & 5 expression was 2-fold higher in GCSC than GSC & [44] \\
\hline EPHA8 & $\begin{array}{l}206 \text { gastric cancer } \\
\text { samples }\end{array}$ & $\begin{array}{l}32 \text { normal gastric } \\
\text { mucosa, } 60 \\
\text { paracancerous } \\
\text { samples }\end{array}$ & $\begin{array}{l}\text { IHC } \\
\text { Western blot }\end{array}$ & $\begin{array}{l}\text { EPH } \\
0 \\
\bigcirc \\
\bigcirc \\
\bigcirc \\
\bigcirc\end{array}$ & $\begin{array}{l}\text { expression associated with: } \\
\text { differentiation level } \\
\text { TNM stage } \\
\text { depth of infiltration } \\
\text { distant metastasis } \\
\text { poor OS }\end{array}$ & [43] \\
\hline ЕРНB2 & $\begin{array}{l}107 \text { gastric } \\
\text { adenocarcinoma } \\
\text { samples ( } 54 \text { of them } \\
\text { received adjuvant } \\
\text { chemotherapy) }\end{array}$ & $\begin{array}{l}\text { Normal paired } \\
\text { gastric samples }\end{array}$ & $\begin{array}{l}\text { Proteome analysis } \\
\text { (LC-MS/MS) } \\
\text { mRNA (real-time } \\
\text { RT-PCR) } \\
\text { IHC }\end{array}$ & - $\quad$ EPI & expression was 2-fold higher in GCSC than GSC & [44] \\
\hline \multirow[b]{2}{*}{ ЕРНВ4 } & $\begin{array}{l}107 \text { gastric } \\
\text { adenocarcinoma } \\
\text { samples ( } 54 \text { of them } \\
\text { received adjuvant } \\
\text { chemotherapy) }\end{array}$ & $\begin{array}{l}\text { Normal paired } \\
\text { gastric samples }\end{array}$ & $\begin{array}{l}\text { Proteome analysis } \\
\text { (LC-MS/MS) } \\
\text { mRNA (real-time } \\
\text { RT-PCR) } \\
\text { IHC }\end{array}$ & \multicolumn{2}{|c|}{ EPHB4 expression was 2-fold higher in GCSC than GSC } & [44] \\
\hline & $\begin{array}{l}31 \text { gastric and GEJ } \\
\text { carcinomas }\end{array}$ & $\begin{array}{l}\text { Paired normal } \\
\text { samples }\end{array}$ & $\begin{array}{l}\text { Quantitative } \\
\text { real-time RT-PCR } \\
\text { IHC }\end{array}$ & $\begin{array}{c}\text { EPH } \\
\bigcirc \\
\bigcirc \\
\bigcirc \\
\bigcirc\end{array}$ & $\begin{array}{l}\text { expression: } \\
\text { high in Barrett esophagus } \\
\text { high in gastroesophageal cancers } \\
\text { associated with advanced tumor stages } \\
\text { high at the tumor invasion front }\end{array}$ & [38] \\
\hline \multirow[b]{2}{*}{ EPHB6 } & $\begin{array}{l}31 \text { gastric and GEJ } \\
\text { carcinomas }\end{array}$ & $\begin{array}{l}\text { Paired normal } \\
\text { samples }\end{array}$ & $\begin{array}{l}\text { Quantitative } \\
\text { real-time RT-PCR } \\
\text { IHC }\end{array}$ & \multicolumn{2}{|c|}{ EPHB6 downregulated in tumor tissues } & [38] \\
\hline & $\begin{array}{l}152 \text { gastric carcinoma } \\
\text { samples }\end{array}$ & & $\mathrm{IHC}$ & $\begin{array}{l}\text { EPHB6 ex } \\
\text { - } \quad \text { Pos } \\
\text { Neg } \\
\bigcirc \\
\bigcirc \\
\bigcirc \\
\text { - Sho } \\
\text { inva }\end{array}$ & $\begin{array}{l}\text { Ssion: } \\
\text { ely associated with tumor differentiation } \\
\text { vely associated with } \\
\text { LN metastasis } \\
\text { tumor stage } \\
\text { female sex } \\
\text { d no association with age/tumor location/depth of } \\
\text { n }\end{array}$ & [46] \\
\hline \multirow{2}{*}{ ephrin-A1 } & $\begin{array}{l}176 \text { gastric } \\
\text { adenocarcinoma } \\
\text { samples }\end{array}$ & $\begin{array}{l}\text { Paired adjacent } \\
\text { normal samples }\end{array}$ & $\begin{array}{l}\text { Real-time RT-PCR } \\
\text { IHC } \\
\text { Western blot }\end{array}$ & \multicolumn{2}{|c|}{$\begin{array}{l}\text { ephrin A1 expression correlated with: } \\
\bigcirc \\
\bigcirc \\
\text { TNM stage } \\
\text { LN metastasis }\end{array}$} & [39] \\
\hline & $\begin{array}{l}46 \text { adenocarcinomas, } 2 \\
\text { adenosquamous } \\
\text { carcinomas, } 1 \\
\text { neuroendocrine } \\
\text { carcinoma }\end{array}$ & $\begin{array}{l}\text { Paired non-tumor } \\
\text { samples }\end{array}$ & $\begin{array}{l}\text { Semiquantitative } \\
\text { RT-PCR } \\
\text { IHC } \\
\text { Western blot }\end{array}$ & \multicolumn{2}{|c|}{$\begin{array}{l}\text { No correlation between ephrin-A1 expression and tumor } \\
\text { size/age/vessel infiltration/LN metastasis }\end{array}$} & [40] \\
\hline ephrin-B1 & $\begin{array}{l}29 \text { gastric carcinoma } \\
\text { samples }\end{array}$ & $\begin{array}{l}\text { Matched normal } \\
\text { samples }\end{array}$ & $\begin{array}{l}\text { Semiquantitative } \\
\text { RT-PCR }\end{array}$ & \multicolumn{2}{|c|}{$\begin{array}{l}\text { ephrin-B1 expression more frequent in poorly } \\
\text { differentiated adenocarcinomas than well-differentiated } \\
\text { ones }\end{array}$} & [45] \\
\hline
\end{tabular}


Table 3. Cont.

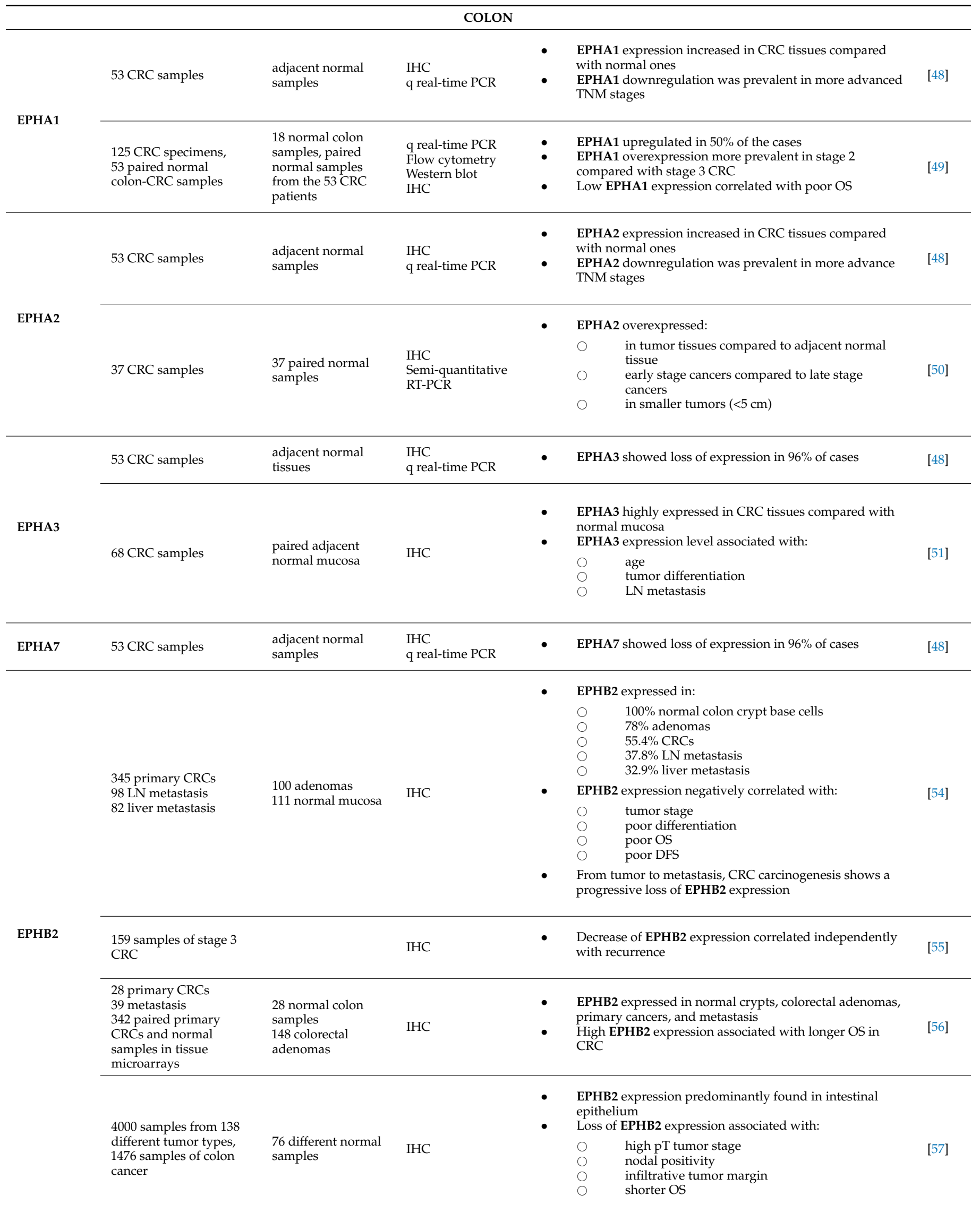


Table 3. Cont.

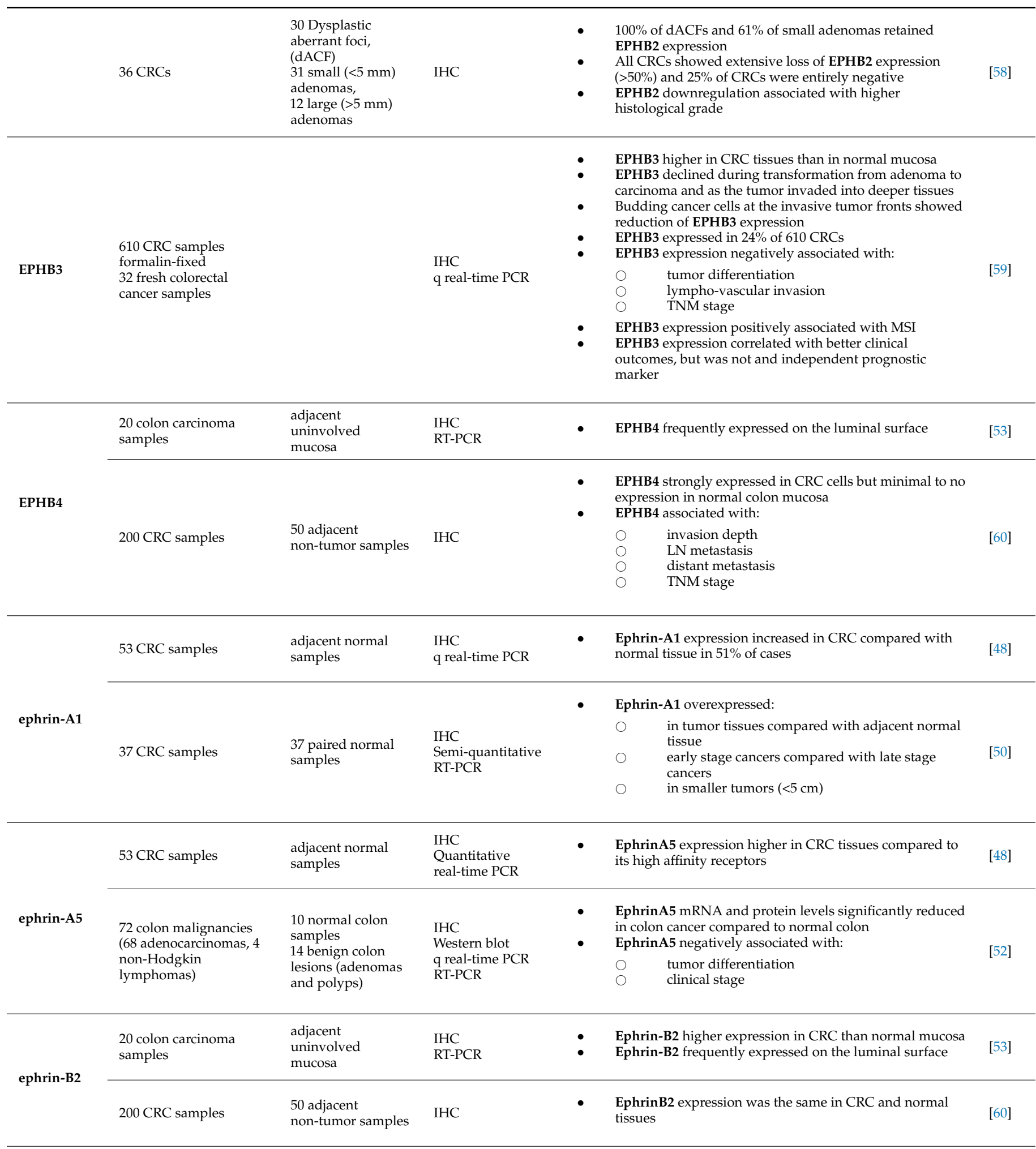


Table 3. Cont.

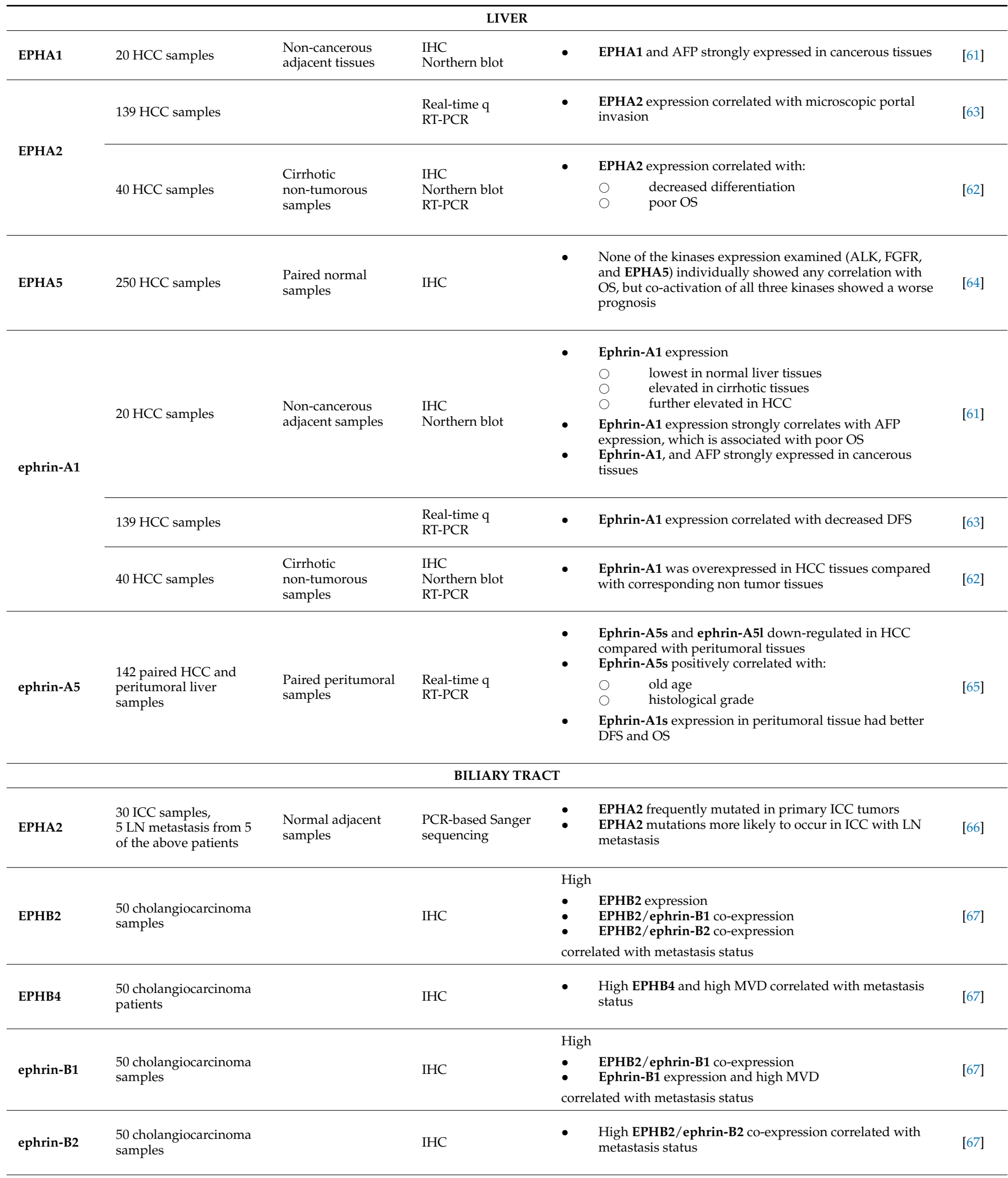


Table 3. Cont.

\begin{tabular}{|c|c|c|c|c|c|c|}
\hline \multicolumn{7}{|c|}{ PANCREAS } \\
\hline \multirow{6}{*}{ ephrin-B2 } & \multirow{3}{*}{$\begin{array}{l}179 \text { PDAC samples } \\
\text { (mRNA data) }\end{array}$} & \multirow{3}{*}{$\begin{array}{l}171 \text { normal } \\
\text { pancreatic samples } \\
\text { (mRNA data) }\end{array}$} & \multirow{3}{*}{ Statistical analysis } & \multirow{2}{*}{\multicolumn{2}{|c|}{$\begin{array}{l}\text { Data analysis of mRNA expression of the } 179 \text { PDAC and } 171 \\
\text { normal pancreatic tissues showed that: } \\
\text { - Ephrin-B2 expression was higher in PDAC tissues than } \\
\text { normal ones } \\
\text { - High ephrin-B2 expression correlated with: }\end{array}$}} & \\
\hline & & & & & & [68] \\
\hline & & & & $\stackrel{\bigcirc}{\bigcirc}$ & $\begin{array}{l}\text { shorter OS } \\
\text { shorter DFS }\end{array}$ & \\
\hline & \multirow{3}{*}{54 PDAC samples } & \multirow{3}{*}{$\begin{array}{l}54 \text { adjacent normal } \\
\text { samples }\end{array}$} & \multirow{3}{*}{$\begin{array}{l}\text { IHC } \\
\text { Quantitative } \\
\text { real-time PCR } \\
\text { Western blot }\end{array}$} & $\begin{array}{l}\text { IHC, qRT- } \\
\text { showed th }\end{array}$ & and western blot analysis of the 54 PDAC tissues & \\
\hline & & & & $\begin{array}{ll}\text { - } & \text { Eph } \\
\text { - } & \text { Hig }\end{array}$ & $\begin{array}{l}\text { B2 expression was higher in PDAC tissues than } \\
\text { ones } \\
\text { hrin-B2 expression correlated with: }\end{array}$ & \\
\hline & & & & $\begin{array}{l}0 \\
0\end{array}$ & $\begin{array}{l}\text { TNM staging } \\
\text { higher ki } 67 \text { expression }\end{array}$ & \\
\hline
\end{tabular}

q PCR: quantitative polymerase chain reaction, IHC: immunohistochemistry, q RT-PCR: quantitative reverse transcription-polymerase chain reaction, q real time PCR: quantitative real time transcription-polymerase chain reaction, GEJ: gastroesophageal junction, LN: lymph nodes, OS: overall survival, DFS: disease-free survival, MVD: microvessel density, GCSC: gastric cancer tissues stromal cells, GSC: normal gastric tissue stromal cells, ICC: intrahepatic cholangiocarcinoma, PDAC: pancreatic ductal adenocarcinoma.

\section{Urinary Tract Neoplasia}

\subsection{Kidney}

\subsubsection{EPHAs}

EPHA1 and EPHA2 proteins expression, although lower in cancer tissues compared with matched non-malignant ones, was observed as higher in metastatic lesions than in primary tumor specimens. Moreover, positive staining of both EPHs was associated with aggressive tumor features, while positive EPHA1 staining was also linked to poor patient OS [69]. Wang et al studied the IHC expression of EPHA3 in 68 samples of Clear Cell Renal Cell Carcinoma (CCRCC) and adjacent normal kidney tissues, reporting its tumor suppressive properties. EPHA3 exhibited strong immunostaining in normal renal tubes, negative expression in $72 \%$ of the CCRCC cases and decreased intensity of immunostaining in positive malignant cases. Loss of EPHA3 expression was positively correlated with tumor size and TNM stage [70].

\subsubsection{EPHBs/Ephrins}

Interestingly, immunohistochemical expression of EPHB4 in the venous endothelium and ephrin-B2 in the arterial endothelium was reported greater in tumoral areas compared with non-tumorous ones [71], possibly underlining the role of the EPH/ephrin system in tumor angiogenesis. Lastly, while ephrin-A1 expression was found to be increased in cancer tissues, its low staining was linked to more aggressive tumor features [69]. All information is presented in Table 4 and Figure 5.

\subsection{Bladder}

\subsubsection{EPHAs}

The EPH/ephrin system is aberrantly expressed in normal urothelium, with its deregulation implicated in the pathogenesis of transitional cell carcinoma (TCC). EPHA2, similarly to its role in kidney cancer, seems to promote TCC development, as it exhibited low expression in normal urothelial cells and was highly expressed in advancing stages of bladder cancer [72].

\subsubsection{EPHBs}

TCC tissues showed loss of EPHB2, which is expressed in normal urothelium. On the other hand, TCC specimens exhibited gain of EPHB4 expression, which is absent in normal urothelium, with the signal strength correlating with the highest tumor stage [73]. In addition, EPHB4 expression in venous endothelium was increased in tumor sections compared with benign ones [71]. 


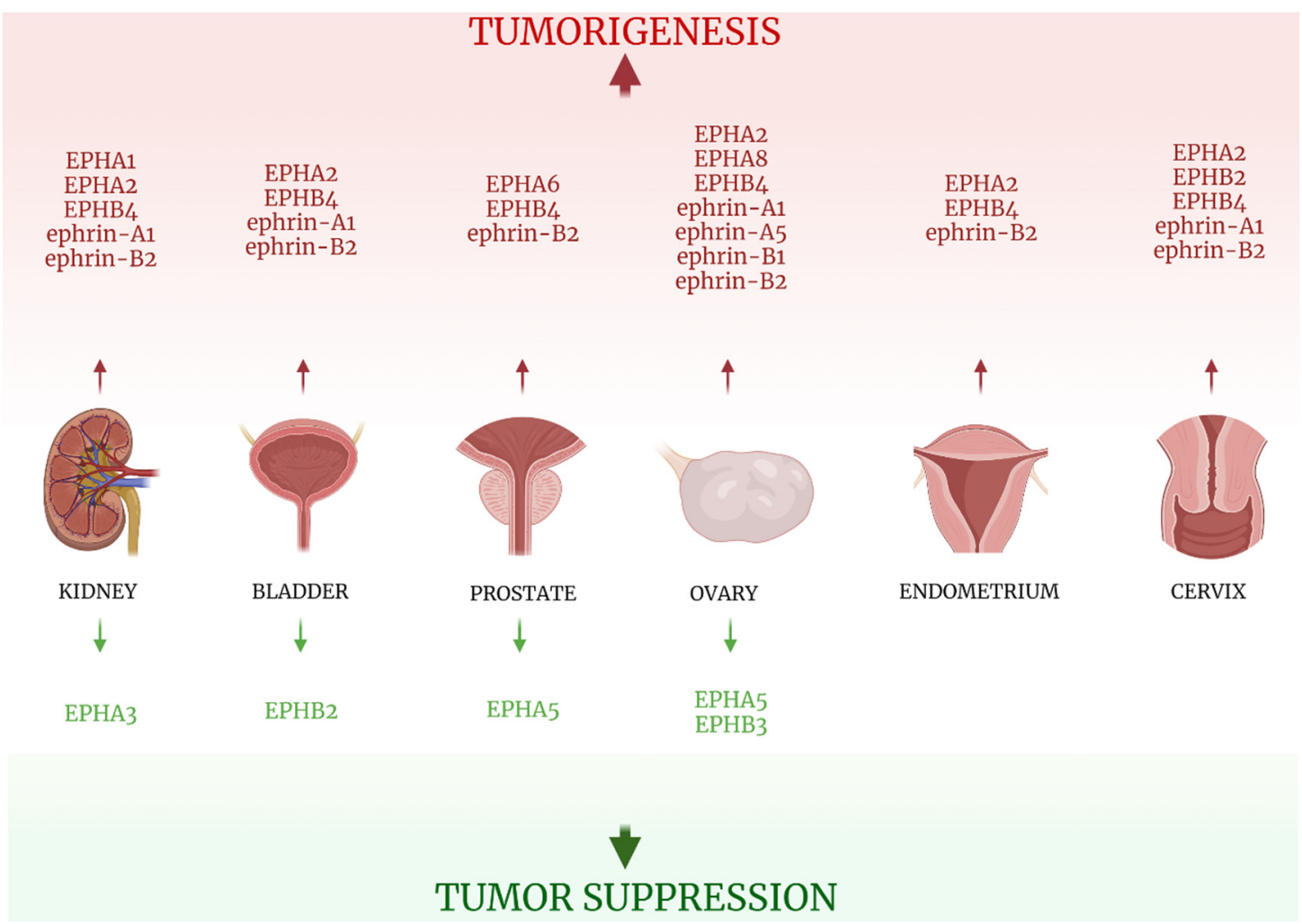

Figure 5. EPH/ephrin family role in solid tumors of organs of the urinary tract, prostate, and gynecological tract. Redcolored EPHs/ephrins enhance tumorigenesis, while green-colored ones suppress it. Created with BioRender.com (accessed on 2 August 2021).

\subsubsection{Ephrins}

Ephrin-B2 expression was associated with poor OS and reduced DFS [74] and noted as higher in arterial endothelium of cancer specimens compared with normal ones [71] Data on EPH/ephrin expression in TCC specimens are presented in Table 4 and Figure 5.

\subsection{Prostate \\ 6.3.1. EPHAs}

Few research data have focused on the role of the EPH/ephrin system in Prostate Cancer (PCa) pathogenesis. EPHA5 is speculated to play a protective role, as loss or downregulation of its expression was reported in $62.2 \%$ of PCa specimens but only in $5.1 \%$ of Benign Prostate Hyperplasia (BPH) samples. Furthermore, patients with an elevated Gleason score or T3-T4 disease stage exhibited higher rates of EPHA5 methylation [75]. EPHA6 $m R N A$ expression, on the other hand, was elevated in PCa tissues compared with benign ones, and was correlated with vascular and neural invasion, as well as with increased serum levels of prostate-specific antigen and high TNM stage [76].

\subsubsection{EPHBs/Ephrin-Bs}

In the study conducted by Özgür et al, that enrolled 20 PCa specimens, EPHB4 expression in venous endothelium and ephrin-B2 expression in arterial endothelium was elevated in tumor areas, compared with benign ones [71].

Information concerning EPH/ephrin expression and its clinical impact in prostate cancer is summarized in Table 4 and Figure 5. 
Table 4. EPHs/ephrins (bold) studied in solid tumors of the urinary tract and prostate and correlations with clinicopathological parameters.

\begin{tabular}{|c|c|c|c|c|c|}
\hline \multicolumn{6}{|c|}{ KIDNEY } \\
\hline EPHs/Ephrins & Malignant Tissues & Benign Control Tissues & Methods & Results & Refs \\
\hline \multirow{4}{*}{ EPHA1 } & $\begin{array}{l}\text { mRNA from } 75 \\
\text { malignant samples }\end{array}$ & $\begin{array}{l}\text { matched non-malignant } \\
\text { samples }\end{array}$ & q PCR & \multirow{2}{*}{$\begin{array}{l}\text { EPHA1 expression lower in cancer tissues than normal ones } \\
\text { Positive EPHA1 staining linked to aggressive tumor } \\
\text { - } \quad \text { Peatures } \\
\text { Positive EPHA1 associated with poor OS } \\
\text { - } \quad \text { Patients with tumors that were: }\end{array}$} & \multirow{4}{*}{ [69] } \\
\hline & \multirow{3}{*}{$\begin{array}{l}\text { protein expression from } \\
241 \text { malignant samples } \\
\text { (primary and } \\
\text { metastatic) }\end{array}$} & \multirow{3}{*}{ non-malignant samples } & \multirow{3}{*}{ TMA IHC } & & \\
\hline & & & & $\begin{array}{ll}\bigcirc & \text { EPHA1/ EPHA2 }(+) \\
\bigcirc & \text { EPHA1/ ephrin-A1 }(+)\end{array}$ & \\
\hline & & & & showed shorter OS & \\
\hline \multirow{4}{*}{ EPHA2 } & $\begin{array}{l}\text { mRNA from } 75 \\
\text { malignant samples }\end{array}$ & $\begin{array}{l}\text { matched non-malignant } \\
\text { samples }\end{array}$ & q PCR & $\begin{array}{l}\text { EPHA2 expression lower in cancer tissues than normal ones } \\
\text { Positive EPHA2 staining linked to aggressive tumor } \\
\text { features }\end{array}$ & \multirow{4}{*}{ [69] } \\
\hline & \multirow{3}{*}{$\begin{array}{l}\text { protein expression from } \\
241 \text { malignant samples } \\
\text { (primary and } \\
\text { metastatic) }\end{array}$} & & & $\begin{array}{l}\text { - } \quad \text { EPHA2 expression higher in metastatic than primary lesions } \\
\text { - } \quad \text { Patients with tumors that were: }\end{array}$ & \\
\hline & & \multirow[t]{2}{*}{ non-malignant samples } & \multirow[t]{2}{*}{ TMA IHC } & $\begin{array}{ll}\bigcirc & \text { EPHA1/ EPHA2 }(+) \\
\bigcirc & \text { EPHA1/ ephrin-A1 }(+)\end{array}$ & \\
\hline & & & & showed shorter OS & \\
\hline
\end{tabular}

- $\quad$ EPHA3 staining:

strong in normal renal tubules

decreased in all CCRCC tissues
absent in $72 \%$ of CCRCC cases

EPHA3 68 CCRCC samples $\begin{aligned} & \text { adjacent normal kidney } \\ & \text { samples }\end{aligned}$

- Loss of EPHA3 was associated with:

tumor diameter

TNM stage

- No association between EPHA3 and sex/age/nuclear grade

\begin{tabular}{|c|c|c|c|c|c|}
\hline ЕРНB4 & $\begin{array}{l}12 \text { kidney cancer } \\
\text { samples }\end{array}$ & & $\begin{array}{l}\text { IHC staining } \\
\text { of arterial and } \\
\text { venous vessels } \\
\text { in tumoral and } \\
\text { non-tumoral } \\
\text { tissues }\end{array}$ & $\begin{array}{l}\text { - Expression of EPHB4 in venous endothelium reported } \\
\text { greater in tumoral sections than in non-tumoral ones }\end{array}$ & {$[71]$} \\
\hline \multirow{2}{*}{ ephrin-A1 } & $\begin{array}{l}\text { mRNA from } 75 \\
\text { malignant samples }\end{array}$ & $\begin{array}{l}\text { matched non-malignant } \\
\text { samples }\end{array}$ & q PCR & $\begin{array}{l}\text { Ephrin-A1 expression higher in cancer tissues than in } \\
\text { normal ones } \\
\text { - } \quad \text { Low ephrin-A1 staining linked to aggressive tumor features } \\
\text { Patients with tumors that were: }\end{array}$ & [69] \\
\hline & $\begin{array}{l}\text { protein expression from } \\
241 \text { malignant samples }\end{array}$ & non-malignant samples & TMA IHC & $\begin{array}{l}\qquad \begin{array}{l}\text { EPHA1/ EPHA2 }(+) \\
\bigcirc\end{array} \text { EPHA1/ ephrin-A1 }(+) \\
\text { showed shorter OS }\end{array}$ & \\
\hline ephrin-B2 & $\begin{array}{l}12 \text { kidney cancer } \\
\text { samples }\end{array}$ & & $\begin{array}{l}\text { IHC staining } \\
\text { of arterial and } \\
\text { venous vessels } \\
\text { in tumoral and } \\
\text { non-tumoral } \\
\text { tissues }\end{array}$ & $\begin{array}{l}\text { Expression of ephrin-B2 in arterial endothelium reported } \\
\text { greater in tumoral sections than non-tumoral ones }\end{array}$ & [71] \\
\hline \multicolumn{6}{|c|}{ BLADDER } \\
\hline EPHs/Ephrins & Malignant Tissues & Benign Control Tissues & Methods & Results & Refs \\
\hline EPHA2 & 64 TCC samples & $\begin{array}{l}13 \text { normal urothelium } \\
\text { samples }\end{array}$ & IHC & $\begin{array}{l}\text { EPHA2 staining intensity lower in normal urothelium and } \\
\text { increased greatly in advancing stages of TCC }\end{array}$ & {$[72]$} \\
\hline EPHB2 & 40 bladder TCC samples & $\begin{array}{l}\text { adjacent non-tumorous } \\
\text { samples }\end{array}$ & $\begin{array}{l}\text { IHC } \\
\text { Western blot }\end{array}$ & $\begin{array}{l}\text { - } \quad \text { Normal urothelium expresses EPHB2 } \\
\text { - } \quad \text { TCC samples showed loss of EPHB2 }\end{array}$ & [73] \\
\hline
\end{tabular}


Table 4. Cont.

\begin{tabular}{|c|c|c|c|c|c|}
\hline \multirow{2}{*}{ ЕРНВ4 } & 40 bladder TCC samples & $\begin{array}{l}\text { adjacent non-tumorous } \\
\text { samples }\end{array}$ & $\begin{array}{l}\text { IHC } \\
\text { Western blot }\end{array}$ & $\begin{array}{l}\text { - Normal urothelium does not express EPHB4 } \\
\text { TCC specimens showed gain of EPHB4 expression } \\
\text { EPHB4 signal strength correlated with highest tumor stage } \\
\text { and trended towards the presence of carcinoma in situ }\end{array}$ & [73] \\
\hline & $\begin{array}{l}33 \text { bladder cancer } \\
\text { samples }\end{array}$ & & $\begin{array}{l}\text { IHC staining } \\
\text { of arterial and } \\
\text { venous vessels } \\
\text { in tumoral and } \\
\text { non-tumoral } \\
\text { tissues }\end{array}$ & $\begin{array}{l}\text { Expression of EPHB4 in venous endothelium reported } \\
\text { greater in tumoral sections than non-tumoral ones }\end{array}$ & [71] \\
\hline ephrin-A1 & 64 TCC samples & $\begin{array}{l}13 \text { normal urothelium } \\
\text { samples }\end{array}$ & IHC & $\begin{array}{l}\text { Ephrin-A1 staining intensity reported low in normal tissues } \\
\text { high in cancerous ones, but similar across the various stages } \\
\text { of TCC }\end{array}$ & {$[72]$} \\
\hline
\end{tabular}

Table 4. Cont.

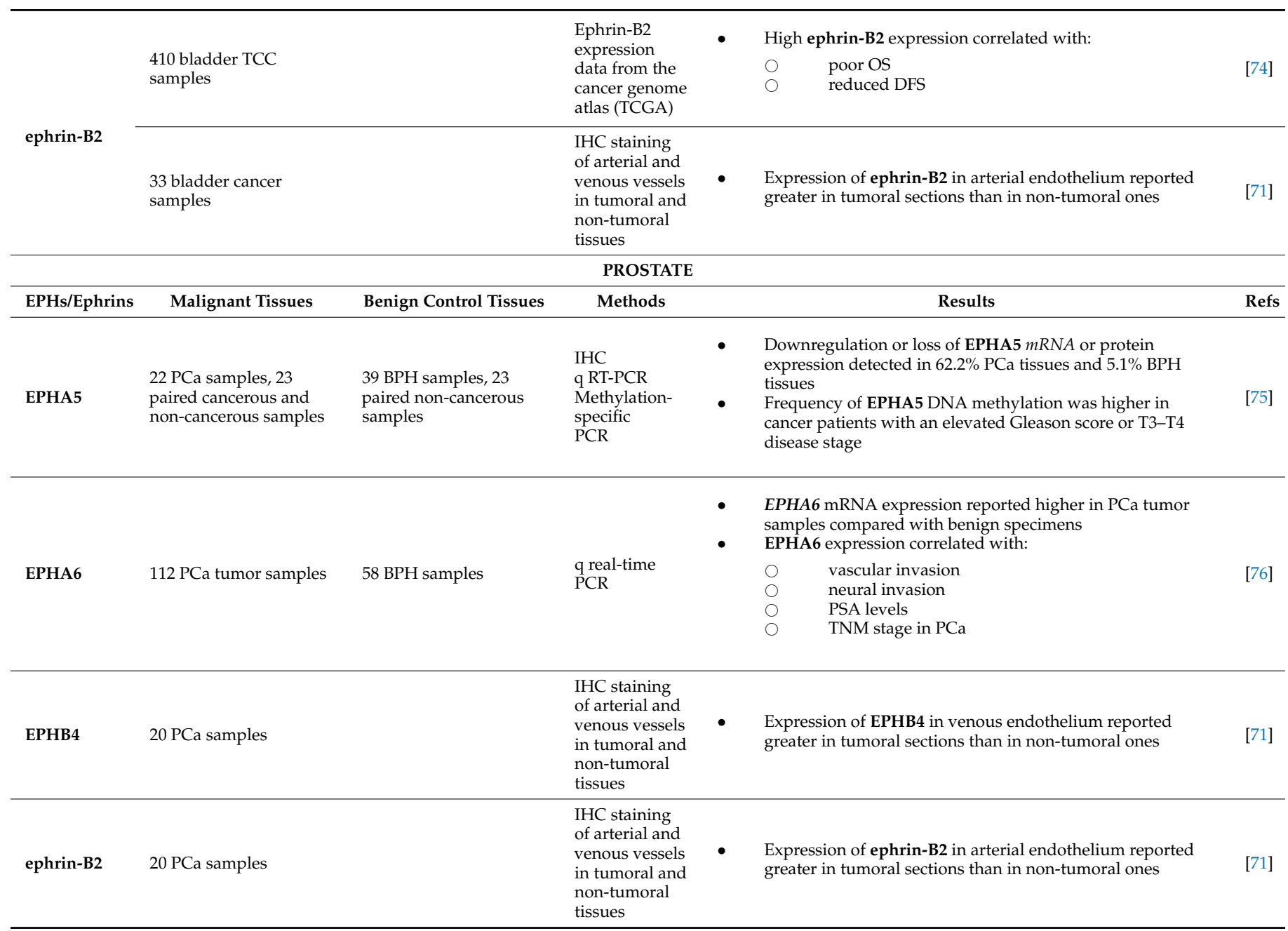

q PCR: quantitative polymerase chain reaction, TMA: tissue microarrays, IHC: immunohistochemistry, q RT-PCR: quantitative reverse transcription-polymerase chain reaction, CCRCC: clear cell renal cell carcinoma, TCC: transitional cell carcinoma, OS: overall survival, DFS: disease-free survival, BPH: benign prostate hyperplasia, $\mathrm{PCa}$ : prostate carcinoma. 


\section{Gynecological Tumors}

\subsection{Ovary}

Gynecological tract neoplasia, along with breast cancer, is greatly impacted by deregulation of the $\mathrm{EPH} /$ ephrin system, with its role in ovarian cancer pathogenesis being amongst the most extensively studied.

\subsubsection{EPHAs}

EPHA1 and EPHA2 expression were reported by Herath et al as having no impact on patients' survival [77]. However, in a large study that included 118 epithelial ovarian carcinoma (EOC) samples, EPHA2 overexpression was correlated with tumors of higher histological grade and shorter patient OS [78]. EPHA5, in consistency with its tumor suppressive properties on other solid tumors [20,75], exhibits a protective role in ovarian cancer, with its negative or weak expression linked to poor clinical outcomes. Downregulation of EPHA5 seems to contribute to carcinogenesis, since from normal fallopian tissues and benign ovarian neoplasms to borderline tumors and serous carcinomas, a progressive loss of EPHA5 expression was noted [79]. EPHA8 overexpression was reported in EOC tissues and was additionally associated with older age, higher disease stage, positive LNs, presence of distant metastasis, positive ascetic fluid, and high CA-125 levels [80].

\subsubsection{EPHBs}

EPHB3 also seems to play a beneficial role in ovarian carcinogenesis, with its expression reduced in serous carcinoma tissues compared with benign ones and its downregulation linked to the histological grade and FIGO stage of serous tumors [81]. High EPHB4 expression, on the other hand, was correlated with clinical stage and low patients' OS [82].

\subsubsection{Ephrins}

Overexpression in cancer tissues of all of the ligands studied (ephrin-A1,-A5,-B1, and -B2) was linked to adverse clinical outcomes and dismal prognoses.

Ephrin-A1 and ephrin-A5 elevated expression in tumorous specimens was linked to decreased survival [77], while ephrin-B1 overexpression, more frequently observed in high-grade carcinomas, was correlated with an increased recurrence rate and decreased OS [83]. Lastly, ephrin-B2 overexpression in cancer tissues was associated with the clinical stage and low patient OS [82].

Data from studies on the role of the EPH/ephrin system on ovarian cancer clinical outcomes are presented in Table 5 and Figure 5.

\subsection{Endometrium}

Kamat et al reported EPHA2 overexpression by IHC in $48 \%$ of 139 endometrial endometrioid carcinoma tissues, but only in $10 \%$ of the 10 benign endometrial specimens. In addition, EPHA2 was positively associated with a plethora of adverse clinical characteristics, such as high disease stage, high tumor grade, increased depth of myometrial invasion, low estrogen and progesterone receptors expression, high Ki67 index, and shorter OS [84]. EPHB4 upregulation were correlated with increased clinical stage, tumor dedifferentiation, deeper myometrial invasion, and low OS [85]. Additionally, according to Dong et al, EPHB4 and ephrin-B2 was associated with estrogen receptor expression [86].

Table 5 and Figure 5 summarize the three studies regarding EPHs/ephrins and endometrial carcinoma. 
Table 5. EPHs/ephrins (bold) studied in solid tumors of the gynecological tract and correlations with clinicopathological parameters.

\begin{tabular}{|c|c|c|c|c|c|}
\hline EPHs/Ephrins & Malignant Tissues & Benign Control Tissues & Methods & Results & Refs \\
\hline \multicolumn{6}{|c|}{ OVARY } \\
\hline EPHA1 & $\begin{array}{l}24 \text { ovarian carcinoma } \\
\text { samples }\end{array}$ & $\begin{array}{l}4 \text { benign ovarian } \\
\text { samples }\end{array}$ & $\begin{array}{l}\text { q real-time } \\
\text { RT-PCR }\end{array}$ & - $\quad$ EPHA1 expression showed no correlation with OS & [77] \\
\hline \multirow[b]{2}{*}{ EPHA2 } & $\begin{array}{l}24 \text { ovarian carcinoma } \\
\text { samples }\end{array}$ & $\begin{array}{l}4 \text { benign ovarian } \\
\text { samples }\end{array}$ & $\begin{array}{l}\text { q real-time } \\
\text { RT-PCR }\end{array}$ & - $\quad$ EPHA2 expression showed no correlation with OS & [77] \\
\hline & 118 EOC samples & & $\begin{array}{l}\text { IHC } \\
\text { RT-PCR }\end{array}$ & $\begin{array}{l}\text { EPHA2 overexpression correlated with higher histological } \\
\text { grade } \\
\text { - } \quad \text { High EPHA2 linked to shorter OS } \\
\text { No correlation between EPHA2 expression and } \\
\text { age/histological type/FIGO stage }\end{array}$ & {$[78]$} \\
\hline
\end{tabular}

\begin{tabular}{|c|c|c|c|}
\hline EPHA5 & $\begin{array}{l}61 \text { ovarian serous } \\
\text { carcinoma samples }\end{array}$ & $\begin{array}{l}24 \text { benign ovarian } \\
\text { serous tumors, } 42 \\
\text { serous borderline } \\
\text { ovarian tumors, } 20 \\
\text { normal fallopian tubes }\end{array}$ & IHC \\
\hline \multirow[b]{2}{*}{ EPHA8 } & $\begin{array}{l}20 \text { fresh-frozen } \\
\text { specimens: } 20 \text { EOC } \\
\text { samples }\end{array}$ & $\begin{array}{l}40 \text { fresh frozen samples: } \\
20 \text { normal ovarian } \\
\text { samples, } \\
20 \text { normal fallopian } \\
\text { tube samples }\end{array}$ & q RT-PCR \\
\hline & $\begin{array}{l}125 \text { paraffin-embedded } \\
\text { EOCs }\end{array}$ & $\begin{array}{l}98 \text { samples } \\
\text { paraffin-embedded: } 30 \\
\text { borderline samples, } 30 \\
\text { benign ovarian tumors, } \\
20 \text { normal fallopian } \\
\text { tubes, } 18 \text { normal } \\
\text { ovarian samples }\end{array}$ & TMA IHC \\
\hline
\end{tabular}

- High EPHA5 expression reported in:

$100 \%$ of benign ovarian serous tumors
$\quad \begin{array}{ll}100 \% \text { of normal fallopian tubes } \\ 76 \% \text { of serous borderline tumors }\end{array}$
$31 \%$ of ovarian serous carcinomas

- $\quad$ Negative or weak EPHA5 expression linked to poor OS

High EPHA8 expression associated with older age/higher stage/(+) LNs/metastasis/(+) ascetic fluid/high CA-125

$\begin{array}{lll}\text { EPHB3 } & \begin{array}{l}50 \text { ovarian serous } \\ \text { carcinomas }\end{array} & \begin{array}{l}17 \text { serous borderline } \\ \text { tumors, } 19 \text { normal } \\ \text { fallopian tubes }\end{array} \\ & \end{array}$
IHC
- $\quad$ EPHB3 expression negatively associated with histological grade and FIGO stage of serous carcinomas
- $\quad$ No correlation between EPHB3 expr and LN status/tumor involvement of uterus/momentum metastasis/abdomen and pelvic metastasis

EPHB3 expression reduced in serous Ca compared with normal fallopian tubes

\begin{tabular}{|c|c|c|c|c|c|}
\hline ЕРНВ4 & $\begin{array}{l}72 \text { ovarian cancer } \\
\text { samples }\end{array}$ & & $\begin{array}{l}\text { IHC } \\
\text { Real-time } \\
\text { RT-PCR }\end{array}$ & $\begin{array}{l}\text { - High EPHB4 expression correlated with clinical stage and } \\
\text { low OS } \\
\text { No correlation between EPHB4 expr levels and histological } \\
\text { type }\end{array}$ & [82] \\
\hline ephrin-A1 & $\begin{array}{l}24 \text { ovarian carcinoma } \\
\text { samples }\end{array}$ & $\begin{array}{l}4 \text { benign ovarian } \\
\text { samples }\end{array}$ & $\begin{array}{l}\text { q real-time } \\
\text { RT-PCR }\end{array}$ & - $\quad$ Ephrin-A1 linked to decreased OS & [77] \\
\hline ephrin-A5 & $\begin{array}{l}24 \text { ovarian carcinoma } \\
\text { samples }\end{array}$ & $\begin{array}{l}4 \text { benign ovarian } \\
\text { samples }\end{array}$ & $\begin{array}{l}\text { q real-time } \\
\text { RT-PCR }\end{array}$ & $\begin{array}{l}\text { Ephrin-A5 linked to decreased OS } \\
\text { Ephrin-A5, among the EPHs/ephrins studies, had the } \\
\text { dominating influence on survival }\end{array}$ & [77] \\
\hline ephrin-B1 & $\begin{array}{l}27 \text { serous adenoCa, } 14 \\
\text { mucinous adenoCa, } 15 \\
\text { clear cell adenoCa, } 15 \\
\text { endometrioid adenoCa }\end{array}$ & $\begin{array}{l}11 \text { serous cystadenomas, } \\
5 \text { mucinous } \\
\text { cystadenomas, } 10 \\
\text { serous borderline } \\
\text { tumors, } 15 \text { muscinous } \\
\text { borderline tumors }\end{array}$ & $\begin{array}{l}\text { IHC } \\
\text { Western blot }\end{array}$ & $\begin{array}{l}\text { Ephrin-B1 expression more frequent in high-grade } \\
\text { carcinomas } \\
\text { High ephrin-B1 expression correlated with increased } \\
\text { reccurence rate and decreased OS }\end{array}$ & [83] \\
\hline ephrin-B2 & $\begin{array}{l}72 \text { ovarian cancer } \\
\text { samples }\end{array}$ & & $\begin{array}{l}\text { IHC } \\
\text { Real-time } \\
\text { RT-PCR }\end{array}$ & $\begin{array}{l}\text { - High ephrin-B2 expression correlated with clinical stage } \\
\text { and low OS } \\
\text { No correlation between ephrin-B2 expr levels and } \\
\text { histological type }\end{array}$ & [82] \\
\hline
\end{tabular}


Table 5. Cont.

ENDOMETRIUM

- High EPHA2 expression detected in $48 \%$ of EECs and $10 \%$ of benign samples

- $\quad$ EPHA2 overexpression associated with

EPHA2 10 benign endometrial IHC

low ER and PR expression

high ki67 index

shorter OS

poor outcome

68 endometrial cancer $\quad 16$ normal endometrium $\quad$ IHC samples RT-PCR
- $\quad$ EPHB4 expression dominant in cancer cells

\section{High EPHB4 expression levels correlated with}

$\bigcirc \quad$ increased clinical stage

$\bigcirc$ dedifferentiation

myometrial invasion

low OS

EPHB4

\begin{tabular}{|c|c|c|}
\hline $\begin{array}{l}11 \mathrm{ER}(+) / \mathrm{PR}(+) \\
\text { endometrial carcinoma } \\
\text { samples, } 33 \text { ER }(-) / \mathrm{PR} \\
(-) \text { endometrial } \\
\text { carcinoma samples }\end{array}$ & $\begin{array}{l}10 \text { adenomyosis } \\
\text { samples, } 2 \text { simple } \\
\text { endometrial } \\
\text { hyperplasia samples, } 20 \\
\text { atypical endometrial } \\
\text { hyperplasia samples }\end{array}$ & $\begin{array}{l}\text { IHC } \\
\text { Western blot }\end{array}$ \\
\hline
\end{tabular}

- $\quad$ Overexpression of EPHB4 detected in er (+)/pr (+)

endometrial carcinomas

- No significant differences in EPHB4 expression between ER

(-)/PR (-) endometrial carcinoma cases and control

specimens reported

- $\quad$ EPHB4 overexpression associated with er expression

- Ephrin-B2 expression dominant in cancer cells

$\begin{array}{lll}\begin{array}{l}68 \text { endometrial cancer } \\ \text { samples }\end{array} & \begin{array}{l}16 \text { normal endometrium } \\ \text { samples }\end{array} & \text { IHC } \\ \text { Real-time }\end{array}$

- High ephrin-B2 expression levels correlated with:

increased clinical stage

dedifferentiation

myometrial invasion

low OS

ephrin-B2

\begin{tabular}{|c|c|c|}
\hline $\begin{array}{l}11 \text { ER }(+) / P R(+) \\
\text { endometrial carcinoma } \\
\text { samples, } 33 \text { ER }(-) / P R \\
\text { (-) endometrial } \\
\text { carcinoma samples }\end{array}$ & $\begin{array}{l}10 \text { adenomyosis } \\
\text { samples, } 2 \text { simple } \\
\text { endometrial } \\
\text { hyperplasia samples, } 20 \\
\text { atypical endometrial } \\
\text { hyperplasia samples }\end{array}$ & $\begin{array}{l}\text { IHC } \\
\text { Western blot }\end{array}$ \\
\hline
\end{tabular}

- $\quad$ Overexpression of ephrin-B2 detected in ER (+)/PR (+)

endometrial carcinomas

- No significant differences in ephrin-B2 expression between ER (-)/PR (-) endometrial carcinoma cases and control

$(-)$ endometrial

atypical endometria

specimens reported

- Ephrin-B2 overexpression associated with er expression

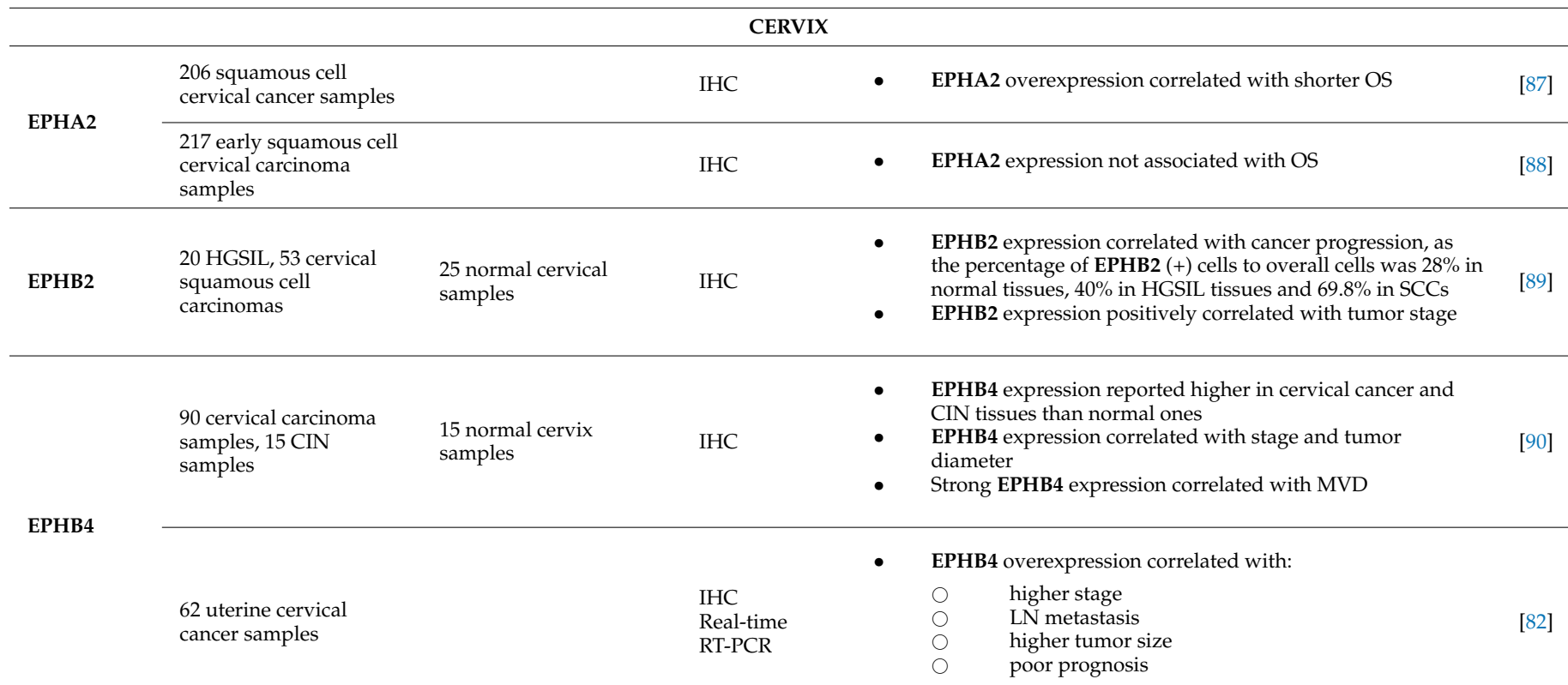


Table 5. Cont.

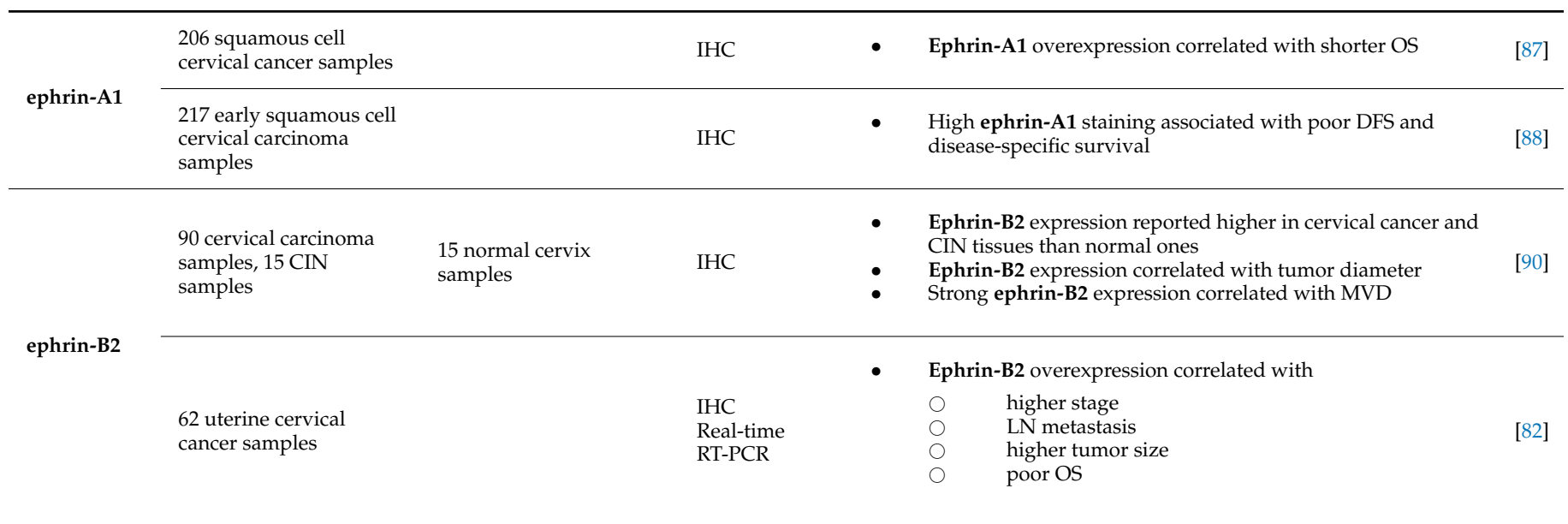

q real time PCR: quantitative real time transcription-polymerase chain reaction, IHC: immunohistochemistry, TMA: tissue microarrays, OS: overall survival, FIGO: International Federation of Gynaecology and Obstetrics, er: estrogen receptor, pr: progesterone receptor, LN: lymph nodes, Ca: carcinoma, MVD: microvessel density, EOC: epithelial ovarian carcinomas, CIN: cervical intraepithelial neoplasm, HGSIL: high-grade squamous intraepithelial lesion.

\subsection{Cervix}

Two large studies, that each incorporated more than 200 Squamous Cell Carcinoma (SCC) specimens, investigated the protein expression of EPHA2 and its ligand, ephrin-A1, through IHC. The first group reported that EPHA2 overexpression was correlated with shorter patient OS [87], while no such association was reached in the second study [88]. However, both studies supported that high ephrin-A1 expression was correlated with poor patient OS. EPHB2 expression correlated with cancer progression, as the percentage of ratio of EPHB2 positive cells to the number of all cells was $28 \%$ in normal tissues, $40 \%$ in High Grade Squamous Intraepithelial Lesion tissues and 69.8\% in SCCs. Furthermore, EPHB2 was positively correlated with tumor stage [89]. Likewise, EPHB4 and ephrin-B2 expression were reported higher in cervical cancer and Cervical Intraepithelial Neoplasia specimens and associated with tumor diameter, with EPHB4 additionally associated with disease stage. EPHB4 and ephrin-B2 may promote tumorigenesis by driving neoangiogenesis, as their strong protein expression is correlated with MVD [90]. Another study linked EPHB4 and ephrin-B2 overexpression to higher tumor stage, LN metastasis, higher tumor size and poorer prognoses [82]. Table 5 and Figure 5 summarize information on EPH/ephrins and cervical cancer.

\section{Pediatric Neoplasia}

\subsection{Sarcomas}

The limited number of studies on the EPH/ephrin system's clinical impact on soft tissue tumors concerns Embryonal Rhabdomyosarcoma (ERM) tumors. EPHA2 and ephrinA1 were reported to be significantly upregulated in ERM tissues compared with normal skeletal muscle specimens [91]. In contrast, EPHB4 overexpression was correlated with positive prognoses (longer OS) for ERM patients [92]. Data are presented on Table 6.

\subsection{Neuroblastoma}

Tang et al [93] investigated, through q PCR, the gene expression of EPHB6, ephrin-B2 and ephrin-B3 in 50 neuroblastoma tissues, associating it with favorable outcomes (longer $\mathrm{OS}$ ), in contrast to the negative role of the aforementioned $\mathrm{EPH} /$ ephrin members in central nervous system neoplasia $[9,12]$. The study is summarized in Table 6.

\subsection{Wilms Tumor}

The investigation of EPHB2 gene expression by q PCR in 25 primary Wilms tumors revealed elevated EPHB2 expression in stages 2-4 compared to stage 1 Wilms tumors, prob- 
ably showing a negative impact on carcinogenesis [94]. The study's results are presented on Table 6.

Table 6. EPHs/ephrins (bold) studied in solid pediatric tumors and correlations with clinicopathological parameters.

\begin{tabular}{|c|c|c|c|c|c|}
\hline EPHs/Ephrins & Malignant Tissues & Benign Control Tissues & Methods & Results & Refs \\
\hline \multicolumn{6}{|c|}{ RHABDOMYOSARCOMA } \\
\hline EPHA2 & 14 ERM samples & $\begin{array}{l}\text { normal skeletal muscle } \\
\text { samples }\end{array}$ & real-time RT-PCR & $\begin{array}{l}\text { Significant } \\
\text { upregulation of } \\
\text { EPHA2 in ERM } \\
\text { tissues compared } \\
\text { to normal skeletal } \\
\text { muscle tissues } \\
\text { reported } \\
\text { No correlation } \\
\text { between EPHA2 } \\
\text { expression and } \\
\text { disease state }\end{array}$ & [91] \\
\hline ЕРHB4 & Not mentioned & & $\begin{array}{c}\text { Data from the } \\
\text { Intergroup } \\
\text { Rhabdomyosarcoma } \\
\text { Study Group (IRSG)-IV } \\
\text { Affymetrix U95 } \\
\text { GeneChip database } \\
\text { regarding EphB4 } \\
\text { expression in human } \\
\text { ERMs }\end{array}$ & $\begin{array}{l}\text { EPHB4 elevated } \\
\text { expression } \\
\text { correlates with } \\
\text { longer OS for } \\
\text { ERM patients }\end{array}$ & [92] \\
\hline ephrin-A1 & 14 ERM samples & $\begin{array}{l}\text { normal skeletal muscle } \\
\text { samples }\end{array}$ & real-time RT-CR & $\begin{array}{l}\text { - Significant } \\
\text { upregulation of } \\
\text { ephrin-A1 in } \\
\text { ERM tissues } \\
\text { compared to } \\
\text { normal skeletal } \\
\text { muscle tissues } \\
\text { reported } \\
\text { No correlation } \\
\text { between } \\
\text { ephrin-A1 } \\
\text { expression and } \\
\text { disease stage }\end{array}$ & [91] \\
\hline
\end{tabular}

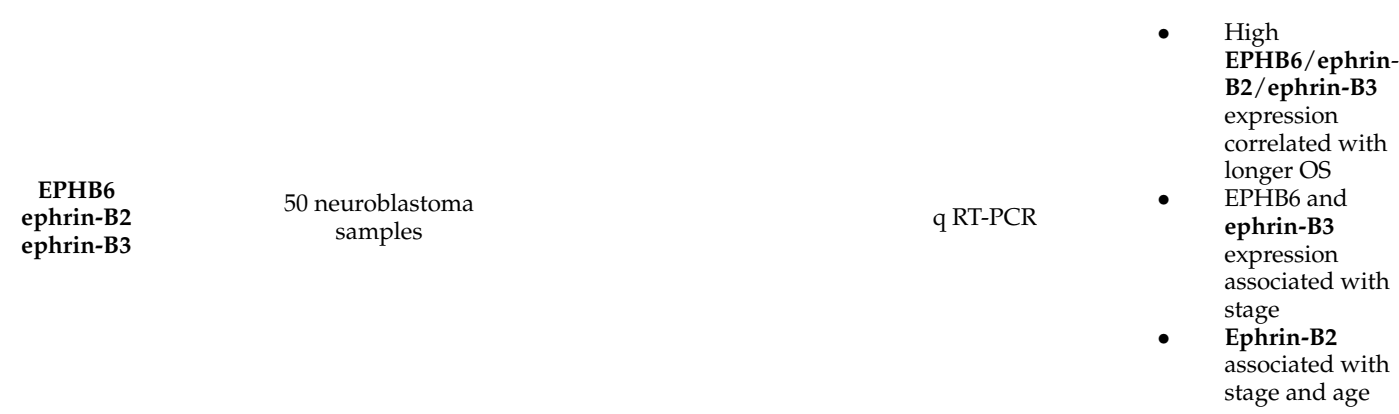

ERM: embryonal rhabdomyosarcoma, real time RT-PCR: real time reverse transcription-polymerase chain reaction, q RT-PCR: quantitative reverse transcription-polymerase chain reaction.

\section{Conclusions}

EPHs/ephrins seem to heavily impact key molecular steps of carcinogenesis. Their role designates them as possible biomarkers, useful in clinical practice for their accuracy, but also for timely detection of the presence of a neoplasm. 
Different members of the EPH/ephrin family carry out distinct actions in different stages of neoplasia. Some members exert their role at early steps of tumorigenesis, aiding tumor cells' proliferation or enhancing the appropriate cell-matrix interactions that allow cancer cells to locally invade surrounding normal tissues. Others are implicated in the creation of the microenvironment that will allow spreading of the tumor to distant sites, carrying out their action in later disease stages. The distinct roles of the EPH/ephrin system members indicate the diversity of their usefulness in the clinical setting. The expression level evaluation of an individual $\mathrm{EPH} /$ ephrin could be utilized to investigate not only the presence of neoplasia, but also the assessment of parameters such as the stage of the disease, the size of the tumor, and the overall disease burden. The EPH/ephrin molecular profile of a tumor should also indicate, in some cases, tumor origin. Moreover, evaluation of the $\mathrm{EPH} /$ ephrin molecular signature of a tumor can accurately estimate patients' prognoses. Determination of fluctuation in their levels could contribute to monitoring treatment efficacy and outcome, as well as to early detection of disease recurrence.

The well-established tumor-promoting or tumor-suppressive properties of the various $\mathrm{EPH} /$ ephrin members renders them potential targets of therapeutic interventions. The development of therapeutic agents blocking EPHs/ephrins that enhance carcinogenesis or enhance the expression of those that suppress it represents a promising future treatment strategy. In addition, researchers have proven that different tumors exhibit distinct profiles of EPH/ephrin protein expression, with some cases showing significant upregulation of a certain member and others extensive loss. The colon is a characteristic example, where the majority of EPHs/ephrins seem to have a protective function regarding neoplastic transformation. Most studies underlined that colon cancer tissues exhibit loss of EPHs/ephrins expression of both subgroups A and B [48-60]. The molecular profile of a tumor could be utilized in order to create a specialized treatment regimen that will benefit each individual patient's prognosis. Antibodies targeting members of the EPH/ephrin system have already been tested in clinical trials. Anti-EPHA2 monoclonal antibody DS-8895a has been tested on esophageal and gastric cancer patients and EPHA3 antibody IIIA4 (Ifabotuzumab/KB004) on GBM cases and patients with hematologic malignancies. As far as antibody-drug conjugates are concerned, an anti-EPHA2 1C1 antibody was evaluated as an auristatin conjugate, MEDI-547, in patients with solid tumors. Furthermore, anti-ephrinA4-Calicheamicin (PF-06647263) has been tested on 60 patients, the majority of whom were diagnosed with ovarian or breast cancer [95]. Research has also been conducted towards the creation of a protein compound with the ability to block EPHB4-ephrin-B2 interaction. The final product, sEphB4-HAS, underwent clinical trial that included 70 patients with various malignancies. Four patients exhibited a response to some extent (1 of 3 Kaposi Sarcoma patients, 2 out of 17 head and neck cancer patients and 1 out of 8 hepatocellular cancer patients), half of the patients had stable disease, and the rest demonstrated disease progression [96,97]. The therapeutic agents targeting members of the EPH/ephrin system that have currently undergone clinical testing are summarized on Table 7.

The role of the microenvironment in tumorigenesis on the organ of origin, as well as the spreading of tumor to distant sites, is often overlooked. EPHs/ephrins are among the molecules implicated in interactions between malignant cells and stromal cells that enhance cancer pathogenesis. It is speculated that EPH/ephrin expression on stromal cells promotes invasion of tumor cells in normal surrounding tissues and also provides a positive feedback for malignant cells' proliferation. EPHA1, EPHA2, EPHA3, EPHA5, EPHB2 and EPHB4 expression has been reported as 2-fold higher in stromal cells isolated from gastric cancer tissues compared with normal gastric tissue stromal cells [44]. Further research on the field of EPH/ephrin stromal cells' molecular profile is called for, as interrupting those mechanisms of communication between tumor cells and cellular components of surrounding connective tissues could represent possible treatment strategies. 
Table 7. Agents (bold) targeting EPHs/ephrins tested in clinical trials.

\begin{tabular}{ccccc}
\hline $\begin{array}{c}\text { Therapeutic } \\
\text { Agent }\end{array}$ & Target & Category & Malignancy & Reference \\
\hline DS-8895a & EPHA2 & $\begin{array}{c}\text { Antibody, } \\
\text { antagonist }\end{array}$ & $\begin{array}{c}\text { Esophageal and } \\
\text { gastric cancer }\end{array}$ & {$[95]$} \\
\hline $\begin{array}{c}\text { Ifabotuzumab } \\
\text { (KB004) }\end{array}$ & EPHA3 & $\begin{array}{c}\text { Antibody, } \\
\text { antagonist }\end{array}$ & $\begin{array}{c}\text { Hematologic } \\
\text { malignancies }\end{array}$ & {$[95]$} \\
\hline MEDI-547 & EPHA2 & $\begin{array}{c}\text { Antibody-drug } \\
\text { conjugate, } \\
\text { agonist }\end{array}$ & $\begin{array}{c}\text { Solid tumors } \\
\text { (various) }\end{array}$ & {$[95]$} \\
\hline PF-06647263 & ephrin-A4 & $\begin{array}{c}\text { Antibody-drug } \\
\text { conjugate, } \\
\text { antagonist }\end{array}$ & $\begin{array}{c}\text { Ovarian and } \\
\text { breast cancer } \\
\text { (majority) }\end{array}$ & {$[95]$} \\
\hline sEphB4-HSA & ephrin-B2 & $\begin{array}{c}\text { Protein complex, } \\
\text { antagonist }\end{array}$ & $\begin{array}{c}\text { Solid and hema- } \\
\text { tologiccancers }\end{array}$ & {$[96,97]$} \\
\hline
\end{tabular}

In practice, researchers have established that the varying expression patterns of the $\mathrm{EPH} /$ ephrin system heavily impact a multitude of clinicopathological parameters. Large studies that enrolled hundreds of patients revealed the correlation between EPHs/ephrins gene or protein expression and disease stage, histological grade and, most importantly, OS and DFS. In vitro studies reported change in cells' biological behavior when certain $\mathrm{EPH} /$ ephrin genes where either upregulated or silenced. However, many questions remain unanswered regarding the role of the EPH/ephrin family in the molecular pathways of neoplasia. The upregulation of a certain EPH can enhance carcinogenesis in one organ, while suppressing it in a different one [56-58,67]. Furthermore, some studies yielded contradictory results regarding the role of EPHs/ephrins in solid tumors. While EPHA1 and EPHA2 showed significantly increased expression in CRC specimens [46-48], they were also associated with lower stage tumors [46-48], and, in the case of EPHA1, with longer patient OS [48]. Moreover, different groups of researchers reported contradicting results on the effect of a distinct $\mathrm{EPH} /$ ephrin in tumorigenesis of an organ, as is the case of EPHA1 in ovarian tumors $[75,76]$. Such discrepancies underline the need of further research on the subject.

In conclusion, the EPH/ephrin system represents a large family of biomolecules with great possible applications in the fields of diagnosis, prognosis, disease monitoring, and treatment of neoplasia, with an established important clinical impact.

Author Contributions: Conceptualization: A.P., E.D. and S.T.; Writing-original draft preparation: A.P.; writing, review and editing: A.P., E.D., D.G., A.G.S. and A.S.; visualization: A.P.; supervision: S.T. All authors have read and agreed to the published version of the manuscript.

Funding: The authors did not receive any external funding.

Institutional Review Board Statement: Not applicable.

Informed Consent Statement: Not applicable.

Conflicts of Interest: The authors declare no conflict of interest. 


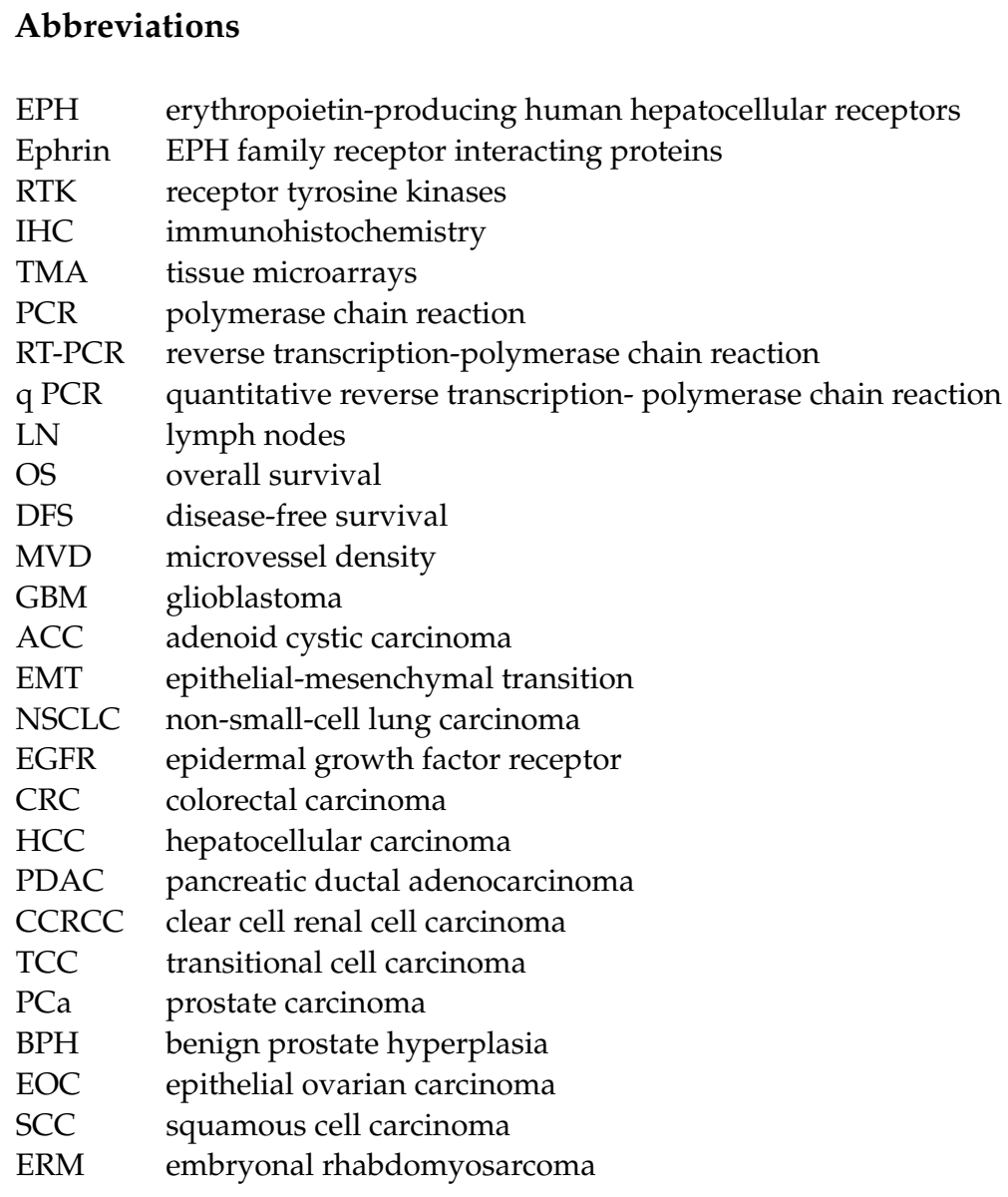

\section{References}

1. Sung, H.; Ferlay, J.; Siegel, R.L.; Laversanne, M.; Soerjomataram, I.; Jemal, A.; Bray, F. Global Cancer Statistics 2020: GLOBOCAN Estimates of Incidence and Mortality Worldwide for 36 Cancers in 185 Countries. CA Cancer J. Clin. 2021, 71, 209-249. [CrossRef]

2. Cancer Statistics-National Cancer Institute. Available online: https://www.cancer.gov/about-cancer/understanding/statistics (accessed on 13 June 2021).

3. Rudno-Rudzińska, J.; Kielan, W.; Frejlich, E.; Kotulski, K.; Hap, W.; Kurnol, K.; Dzierżek, P.; Zawadzki, M.; Hałoń, A. A review on Eph/ephrin, angiogenesis and lymphangiogenesis in gastric, colorectal and pancreatic cancers. Chin. J. Cancer Res. 2017, 29, 303-312. [CrossRef]

4. Jones, D. Parallels of Resistance between Angiogenesis and Lymphangiogenesis Inhibition in Cancer Therapy. Cells 2020, 9, 762. [CrossRef]

5. Kou, C.-T.J.; Kandpal, R.P. Differential Expression Patterns of Eph Receptors and Ephrin Ligands in Human Cancers. BioMed Res. Int. 2018, 2018, 7390104. [CrossRef]

6. $\quad$ Li, X.; Wang, L.; Gu, J.-W.; Li, B.; Liu, W.-P.; Wang, Y.-G.; Zhang, X.; Zhen, H.-N.; Fei, Z. Up-regulation of EphA2 and downregulation of EphrinA1 are associated with the aggressive phenotype and poor prognosis of malignant glioma. Tumor Biol. 2010, 31, 477-488. [CrossRef]

7. Liu, F.; Park, P.J.; Lai, W.; Maher, E.; Chakravarti, A.; Durso, L.; Jiang, X.; Yu, Y.; Brosius, A.; Thomas, M.; et al. A Genome-Wide Screen Reveals Functional Gene Clusters in the Cancer Genome and Identifies EphA2 as a Mitogen in Glioblastoma. Cancer Res. 2006, 66, 10815-10823. [CrossRef]

8. Suo, F.; Zhong, B.; Lu, F.; Dong, Z. The combined use of EphA2/MMP-2 expression and MRI findings contributes to the determination of cerebral glioma grade. Oncol. Lett. 2019, 18, 5607-5613. [CrossRef]

9. Royet, A.; Broutier, L.; Coissieux, M.-M.; Malleval, C.; Gadot, N.; Maillet, D.; Gratadou-Hupon, L.; Bernet, A.; Nony, P.; Treilleux, I.; et al. Ephrin-B3 supports glioblastoma growth by inhibiting apoptosis induced by the dependence receptor EphA4. Oncotarget 2017, 8, 23750-23759. [CrossRef]

10. Wang, L.-F.; Fokas, E.; Juricko, J.; You, A.; Rose, F.; Pagenstecher, A.; Engenhart-Cabillic, R.; Janko, J. Increased expression of EphA7 correlates with adverse outcome in primary and recurrent glioblastoma multiforme patients. BMC Cancer 2008, 8, 79. [CrossRef]

11. Teng, L.; Nakada, M.; Furuyama, N.; Sabit, H.; Furuta, T.; Hayashi, Y.; Takino, T.; Dong, Y.; Sato, H.; Sai, Y.; et al. Ligand-dependent EphB1 signaling suppresses glioma invasion and correlates with patient survival. Neuro Oncol. 2013, 15, 1710-1720. [CrossRef] 
12. Tu, Y.; He, S.; Fu, J.; Li, G.; Xu, R.; Lu, H.; Deng, J. Expression of EphrinB2 and EphB4 in glioma tissues correlated to the progression of glioma and the prognosis of glioblastoma patients. Clin. Transl. Oncol. 2012, 14, 214-220. [CrossRef] [PubMed]

13. Shao, Z.; Zhu, F.; Song, K.; Zhang, H.; Liu, K.; Shang, Z. EphA2/EphrinA1 mRNA Expression and Protein Production in Adenoid Cystic Carcinoma of Salivary Gland. J. Oral Maxillofac. Surg. 2013, 71, 869-878. [CrossRef] [PubMed]

14. Fukai, J.; Fujita, K.; Yamoto, T.; Sasaki, T.; Uematsu, Y.; Nakao, N. Intracranial extension of adenoid cystic carcinoma: Potential involvement of EphA2 expression and epithelial-mesenchymal transition in tumor metastasis: A case report. BMC Res. Notes 2014, 7, 131. [CrossRef]

15. Karidis, N.P.; Giaginis, C.; Tsourouflis, G.; Alexandrou, P.; Delladetsima, I.; Theocharis, S. Eph-A2 and Eph-A4 expression in human benign and malignant thyroid lesions: An immunohistochemical study. Med. Sci. Monit. 2011, 17, BR257-BR265. [CrossRef]

16. Qin, C.; Cau, W.; Zhang, Y.; Mghanga, F.P.; Lan, X.; Gao, Z.; An, R. Correlation of Clinicopathological Features and Expression of Molecular Markers With Prognosis After 131I Treatment of Differentiated Thyroid Carcinoma. Clin. Nucl. Med. 2012, 37, e40-e46. [CrossRef] [PubMed]

17. Giaginis, C.; Alexandrou, P.; Poulaki, E.; Delladetsima, I.; Troungos, C.; Patsouris, E.; Theocharis, S. Clinical Significance of EphB4 and EphB6 Expression in Human Malignant and Benign Thyroid Lesions. Pathol. Oncol. Res. 2015, 22, 269-275. [CrossRef]

18. Sharma, G.K.; Dhillon, V.K.; Masood, R.; Maceri, D.R. Overexpression of EphB4, EphrinB2, and epidermal growth factor receptor in papillary thyroid carcinoma: A pilot study. Head Neck 2014, 37, 964-969. [CrossRef]

19. Kebebew, E.; Peng, M.; Reiff, E.; Duh, Q.-Y.; Clark, O.H.; McMillan, A. Diagnostic and prognostic value of angiogenesismodulating genes in malignant thyroid neoplasms. Surgery 2005, 138, 1102-1110. [CrossRef]

20. Giaginis, C.; Tsoukalas, N.; Bournakis, E.; Alexandrou, P.; Kavantzas, N.; Patsouris, E.; Theocharis, S. Ephrin (Eph) receptor A1, A4, A5 and A7 expression in human non-small cell lung carcinoma: Associations with clinicopathological parameters, tumor proliferative capacity and patients' survival. BMC Clin. Pathol. 2014, 14, 8. [CrossRef]

21. Efazat, G.; Novak, M.; Kaminskyy, V.O.; De Petris, L.; Kanter, L.; Juntti, T.; Bergman, P.; Zhivotovsky, B.; Lewensohn, R.; Hååg, P.; et al. Ephrin B3 interacts with multiple EphA receptors and drives migration and invasion in non-small cell lung cancer. Oncotarget 2016, 7, 60332-60347. [CrossRef]

22. Ishikawa, M.; Miyahara, R.; Sonobe, M.; Horiuchi, M.; Mennju, T.; Nakayama, E.; Kobayashi, M.; Kikuchi, R.; Kitamura, J.; Imamura, N.; et al. Higher expression of EphA2 and ephrin-A1 is related to favorable clinicopathological features in pathological stage I non-small cell lung carcinoma. Lung Cancer 2012, 76, 431-438. [CrossRef]

23. Wang, L.; Peng, Q.; Sai, B.; Zheng, L.; Xu, J.; Yin, N.; Feng, X.; Xiang, J. Ligand-independent EphB1 signaling mediates TGF- $\beta$-activated CDH2 and promotes lung cancer cell invasion and migration. J. Cancer 2020, 11, 4123-4131. [CrossRef]

24. Zhao, C.; Wang, A.; Lu, F.; Chen, H.; Fu, P.; Zhao, X.; Chen, H. Overexpression of junctional adhesion molecule-A and EphB2 predicts poor survival in lung adenocarcinoma patients. Tumor Biol. 2017, 39, 1010428317691000. [CrossRef]

25. Li, J.; Sun, Y.; Wang, X.; Wang, J.; Zhu, Y. The expressions of EphB4 and ephrinB2 in lung adenocarcinomas: A high level of the EphB4 protein is associated with lymph node metastasis. Int. J. Clin. Exp. Pathol. 2019, 12, 3447-3452.

26. Rud, A.K.; Boye, K.; Øijordsbakken, M.; Lund-Iversen, M.; Halvorsen, A.R.; Solberg, S.K.; Berge, G.; Helland, A.; Brustugun, O.T.; Mælandsmo, G.M. Osteopontin is a prognostic biomarker in non-small cell lung cancer. BMC Cancer 2013, 13, 540. [CrossRef] [PubMed]

27. Husa, A.-M.; Magić, Z.; Larsson, M.; Fornander, T.; Pérez-Tenorio, G. EPH/ephrin profile and EPHB2 expression predicts patient survival in breast cancer. Oncotarget 2016, 7, 21362-21380. [CrossRef] [PubMed]

28. Brantley-Sieders, D.M.; Jiang, A.; Sarma, K.; Badu-Nkansah, A.; Walter, D.L.; Shyr, Y.; Chen, J. Eph/Ephrin Profiling in Human Breast Cancer Reveals Significant Associations between Expression Level and Clinical Outcome. PLoS ONE 2011, 6, e24426. [CrossRef] [PubMed]

29. Hachim, I.Y.; Villatoro, M.; Canaff, L.; Hachim, M.; Boudreault, J.; Haiub, H.; Ali, S.; Lebrun, J.-J. Transforming Growth Factor-beta Regulation of Ephrin Type-A Receptor 4 Signaling in Breast Cancer Cellular Migration. Sci. Rep. 2017, 7, 14976. [CrossRef]

30. Mu, X.; Huang, O.; Jiang, M.; Xie, Z.; Chen, D.; Zhang, X. Prognostic value of ephrin B receptors in breast cancer: An online survival analysis using the microarray data of 3554 patients. Oncol. Lett. 2019, 18, 742-750. [CrossRef]

31. Wu, Q.; Suo, Z.; Risberg, B.; Karlsson, M.G.; Villman, K.; Nesland, J.M. Expression of Ephb2 And Ephb4 in Breast Carci-noma. Pathol. Oncol. Res. 2004, 10, 26-33. [CrossRef]

32. Magic, Z.; Perez-Tenorio, G. Ephrin-B2 inhibits cell proliferation and motility in vitro and predicts longer metastasis-free survival in breast cancer. Int. J. Oncol. 2019, 55, 1275-1286. [CrossRef]

33. Fernández-Nogueira, P.; Bragado, P.; Almendro, V.; Ametller, E.; Rios, J.; Choudhury, S.; Mancino, M.; Gascón, P. Differential expression of neurogenes among breast cancer subtypes identifies high risk pa-tients. Oncotarget 2015, 7, 5313-5326. Available online: www.impactjournals.com/oncotarget (accessed on 2 August 2021). [CrossRef]

34. Yin, H.; Lu, C.; Tang, Y.; Wang, H.; Wang, H.; Wang, J. Enhanced expression of EphrinB1 is associated with lymph node metastasis and poor prognosis in breast cancer. Cancer Biomark. 2013, 13, 261-267. [CrossRef]

35. Hafner, C.; Becker, B.; Landthaler, M.; Vogt, T. Expression profile of Eph receptors and ephrin ligands in human skin and downregulation of EphA1 in nonmelanoma skin cancer. Mod. Pathol. 2006, 19, 1369-1377. [CrossRef] 
36. Straume, O.; Akslen, L.A. Importance of Vascular Phenotype by Basic Fibroblast Growth Factor, and Influence of the Angiogenic Factors Basic Fibroblast Growth Factor/Fibroblast Growth Factor Receptor-1 and Ephrin-A1/EphA2 on Mela-noma Progression. Am. J. Pathol. 2002, 160, 1009-1019. [CrossRef]

37. Schauer, M.C.; Stoecklein, N.H.; Theisen, J.; Kröpil, F.; Baldus, S.; Hoelscher, A.; Feith, M.; Bölke, E.; Matuschek, C.; Budach, W.; et al. The simultaneous expression of both ephrin B3 receptor and E-cadherin in Barrett's adenocarcinoma is associated with favorable clinical staging. Eur. J. Med. Res. 2012, 17, 10. [CrossRef]

38. Liersch-Löhn, B.; Slavova, N.; Buhr, H.J.; Bennani-Baiti, I.M. Differential protein expression and oncogenic gene network link tyrosine kinase ephrin B4 receptor to aggressive gastric and gastroesophageal junction cancers. Int. J. Cancer 2015, 138, 1220-1231. [CrossRef]

39. Yuan, W.-J.; Ge, J.; Chen, Z.-K.; Wu, S.-B.; Shen, H.; Yang, P.; Hu, B.; Zhang, G.-W.; Chen, Z.-H. Over-Expression of EphA2 and EphrinA-1 in Human Gastric Adenocarcinoma and Its Prognostic Value for Postoperative Patients. Dig. Dis. Sci. 2008, 54, 2410-2417. [CrossRef]

40. Nakamura, R.; Kataoka, H.; Sato, N.; Kanamori, M.; Ihara, M.; Igarashi, H.; Ravshanov, S.; Wang, Y.-J.; Li, Z.-Y.; Shimamura, T.; et al. EPHA2/EFNA1 expression in human gastric cancer. Cancer Sci. 2005, 96, 42-47. [CrossRef]

41. Hong, H.N.; Won, Y.J.; Shim, J.H.; Kim, H.J.; Han, S.H.; Kim, B.S.; Kim, H.S. Cancer-associated fibroblasts promote gastric tumorigenesis through EphA2 activation in a ligand-independent manner. J. Cancer Res. Clin. Oncol. 2018, 144, 1649-1663. [CrossRef]

42. Oki, M.; Yamamoto, H.; Taniguchi, H.; Adachi, Y.; Imai, K.; Shinomura, Y. Overexpression of the receptor tyrosine kinase EphA4 in human gastric cancers. World J. Gastroenterol. 2008, 14, 5650-5656. [CrossRef]

43. Wang, Y.; Zhou, N.; Li, P.; Wu, H.; Wang, Q.; Gao, X.; Wang, X.; Huang, J. EphA8 acts as an oncogene and contributes to poor prognosis in gastric cancer via regulation of ADAM10. J. Cell. Physiol. 2019, 234, 20408-20419. [CrossRef] [PubMed]

44. Kikuchi, S.; Kaibe, N.; Morimoto, K.; Fukui, H.; Niwa, H.; Maeyama, Y.; Takemura, M.; Matsumoto, M.; Nakamori, S.; Miwa, H.; et al. Overexpression of Ephrin A2 receptors in cancer stromal cells is a prognostic factor for the relapse of gastric cancer. Gastric Cancer 2014, 18, 485-494. [CrossRef] [PubMed]

45. Kataoka, H.; Tanaka, M.; Kanamori, M.; Yoshii, S.; Ihara, M.; Wang, Y.-J.; Song, J.-P.; Li, Z.-Y.; Arai, H.; Otsuki, Y.; et al. Expression profile of EFNB1, EFNB2, two ligands of EPHB2 in human gastric cancer. J. Cancer Res. Clin. Oncol. 2002, 128, 343-348. [CrossRef]

46. Liu, J.; Bin Xu, B.; Xu, G.; Zhang, X.; Yang, X.; Wang, J. Reduced EphB6 protein in gastric carcinoma and associated lymph nodes suggests EphB6 as a gastric tumor and metastasis inhibitor. Cancer Biomark. 2017, 19, 241-248. [CrossRef]

47. Rawla, P.; Sunkara, T.; Barsouk, A. Epidemiology of colorectal cancer: Incidence, mortality, survival, and risk factors. Gastroenterol. Rev. 2019, 14, 89-103. [CrossRef]

48. Herath, N.I.; Spanevello, M.D.; Doecke, J.D.; Smith, F.M.; Pouponnot, C.; Boyd, A.W. Complex expression patterns of Eph receptor tyrosine kinases and their ephrin ligands in colorectal carcinogenesis. Eur. J. Cancer 2012, 48, 753-762. [CrossRef]

49. Herath, N.I.; Doecke, J.; Spanevello, M.D.; Leggett, B.; Boyd, A.W. Epigenetic silencing of EphA1 expression in colorectal cancer is correlated with poor survival. Br. J. Cancer 2009, 100, 1095-1102. [CrossRef]

50. Kataoka, H.; Igarashi, H.; Kanamori, M.; Ihara, M.; Wang, J.-D.; Wang, Y.-J.; Li, Z.-Y.; Shimamura, T.; Kobayashi, T.; Maruyama, K.; et al. Correlation of EPHA2 overexpression with high microvessel count in human primary colorectal cancer. Cancer Sci. 2004, 95, 136-141. [CrossRef] [PubMed]

51. Li, M.; Yang, C.; Liu, X.; Yuan, L.; Zhang, F.; Wang, M.; Miao, D.; Gu, X.; Jiang, S.; Cui, B.; et al. EphA3 promotes malignant transformation of colorectal epithelial cells by upregulating oncogenic pathways. Cancer Lett. 2016, 383, 195-203. [CrossRef]

52. Wang, T.-H.; Chang, J.-L.; Ho, J.-Y.; Wu, H.-C.; Chen, T.-C. EphrinA5 suppresses colon cancer development by negatively regulating epidermal growth factor receptor stability. FEBS J. 2011, 279, 251-263. [CrossRef] [PubMed]

53. Liu, W.; Ahmad, S.A.; Jung, Y.D.; Reinmuth, N.; Fan, B.S.F.; Bucana, C.D.; Ellis, L.M. Coexpression of ephrin-Bs and their receptors in colon carcinoma. Cancer 2002, 94, 934-939. [CrossRef]

54. Guo, D.L.; Tsui, W.Y.; Chan, A.S.; Ho, C.; Leung, S.Y.; Zhang, J.; Yuen, S.T.; Ji, J.; Chen, X. Reduced expression of EphB2 that parallels invasion and metastasis in colorectal tumours. Carcinogenesis 2005, 27, 454-464. [CrossRef]

55. Drucker, A.; Arnason, T.; Sen, R.Y.; Aljawad, M.; Thompson, K.; Huang, W.-Y. Ephrin B2 Receptor and Microsatellite Status in Lymph Node-Positive Colon Cancer Survival. Transl. Oncol. 2013, 6, 520-527. [CrossRef]

56. Jubb, A.M.; Zhong, F.; Bheddah, S.; Grabsch, H.I.; Frantz, G.D.; Mueller, W.; Kavi, V.; Quirke, P.; Polakis, P.; Koeppen, H. EphB2 is a Prognostic Factor in Colorectal Cancer. Clin. Cancer Res. 2005, 11, 5181-5187. [CrossRef]

57. Lugli, A.; Spichtin, H.; Maurer, R.; Mirlacher, M.; Kiefer, J.; Huusko, P.; Azorsa, D.; Terracciano, L.; Sauter, G.; Kallioniemi, O.; et al. EphB2 Expression across 138 Human Tumor Types in a Tissue Microarray: High Levels of Expression in Gastrointestinal Cancers. Clin. Cancer Res. 2005, 11, 6450-6458. [CrossRef] [PubMed]

58. Batlle, E.; Bacani, J.; Begthel, H.; Jonkheer, S.; Gregorieff, A.; Van De Born, M.; Malats, N.; Sancho, E.; Boon, E.; Pawson, T.; et al. EphB receptor activity suppresses colorectal cancer progression. Nat. Cell Biol. 2005, 435, 1126-1130. [CrossRef]

59. Jang, B.G.; Kim, H.S.; Bae, J.M.; Kim, W.H.; Hyun, C.L.; Kang, G.H. Expression Profile and Prognostic Significance of EPHB3 in Colorectal Cancer. Biomolecules 2020, 10, 602. [CrossRef]

60. Lv, J.; Xia, Q.; Wang, J.; Shen, Q.; Zhang, J.; Zhou, X. EphB4 promotes the proliferation, invasion, and angiogenesis of human colorectal cancer. Exp. Mol. Pathol. 2016, 100, 402-408. [CrossRef] 
61. Iida, H.; Honda, M.; Kawai, H.F.; Yamashita, T.; Shirota, Y.; Wang, B.-C.; Miao, H.; Kaneko, S. Ephrin-A1 expression contributes to the malignant characteristics of -fetoprotein producing hepatocellular carcinoma. Gut 2005, 54, 843-851. [CrossRef] [PubMed]

62. Cui, X.-D.; Lee, M.-J.; Yu, G.-R.; Kim, I.-H.; Yu, H.-C.; Song, E.-Y.; Kim, D.-G. EFNA1 ligand and its receptor EphA2: Potential biomarkers for hepatocellular carcinoma. Int. J. Cancer 2009, 126, 940-949. [CrossRef]

63. Wada, H.; Yamamoto, H.; Kim, C.; Uemura, M.; Akita, H.; Tomimaru, Y.; Hama, N.; Kawamoto, K.; Kobayashi, S.; Eguchi, H.; et al. Association between ephrin-A1 mRNA expression and poor prognosis after hepatectomy to treat hepatocellular carcinoma. Int. J. Oncol. 2014, 45, 1051-1058. [CrossRef]

64. Wang, X.; Zhang, M.; Ping, F.; Liu, H.; Sun, J.; Wang, Y.; Shen, A.; Ding, J.; Geng, M. Identification and Therapeutic Intervention of Coactivated Anaplastic Lymphoma Kinase, Fibroblast Growth Factor Receptor 2, and Ephrin Type-A Receptor 5 Kinases in Hepatocellular Carcinoma. Hepatology 2019, 69, 573-586. [CrossRef]

65. Wang, T.-H.; Ng, K.-F.; Yeh, T.-S.; Wang, Y.-L.; Liang, K.-H.; Yeh, C.-T.; Chen, T.-C. Peritumoral Small EphrinA5 Isoform Level Predicts the Postoperative Survival in Hepatocellular Carcinoma. PLoS ONE 2012, 7, e41749. [CrossRef]

66. Sheng, Y.; Wei, J.; Zhang, Y.; Gao, X.; Wang, Z.; Yang, J.; Yan, S.; Zhu, Y.; Zhang, Z.; Xu, D.; et al. Mutated EPHA2 is a target for combating lymphatic metastasis in intrahepatic cholangiocarcinoma. Int. J. Cancer 2018, 144, 2440-2452. [CrossRef] [PubMed]

67. Khansaard, W.; Techasen, A.; Namwat, N.; Yongvanit, P.; Khuntikeo, N.; Puapairoj, A.; Loilome, W. Increased EphB2 expression predicts cholangiocarcinoma metastasis. Tumor Biol. 2014, 35, 10031-10041. [CrossRef] [PubMed]

68. Zhu, F.; Dai, S.-N.; Xu, D.-L.; Hou, C.-Q.; Liu, T.-T.; Chen, Q.-Y.; Wu, J.-L.; Miao, Y. EFNB2 facilitates cell proliferation, migration, and invasion in pancreatic ductal adenocarcinoma via the p53/p21 pathway and EMT. Biomed. Pharmacother. 2020, 125, 109972. [CrossRef] [PubMed]

69. Toma, M.I.; Erdmann, K.; Diezel, M.; Meinhardt, M.; Zastrow, S.; Fuessel, S.; Wirth, M.P.; Baretton, G.B. Lack of Ephrin Receptor A1 Is a Favorable Independent Prognostic Factor in Clear Cell Renal Cell Carcinoma. PLoS ONE 2014, 9, e102262. [CrossRef] [PubMed]

70. Wang, X.; Xu, H.; Cao, G.; Wu, Z.; Wang, J. Loss of EphA3 Protein Expression Is Associated With Advanced TNM Stage in Clear-Cell Renal Cell Carcinoma. Clin. Genitourin. Cancer 2017, 15, e169-e173. [CrossRef]

71. Özgür, E.; Heidenreich, A.; Dagtekin, O.; Engelmann, U.; Bloch, W. Distribution of EphB4 and EphrinB2 in normal and malignant urogenital tissue. Urol. Oncol. Semin. Orig. Investig. 2011, 29, 78-84. [CrossRef]

72. Abraham, S.; Knapp, D.W.; Cheng, L.; Snyder, P.W.; Mittal, S.K.; Bangari, D.S.; Kinch, M.; Wu, L.; Dhariwal, J.; Mohammed, S.I. Expression of EphA2 and Ephrin A-1 in Carcinoma of the Urinary Bladder. Clin. Cancer Res. 2006, 12, 353-360. [CrossRef]

73. Li, X.; Choi, W.W.; Yan, R.; Yu, H.; Krasnoperov, V.; Kumar, S.R.; Schuckman, A.; Klumpp, D.J.; Pan, C.-X.; Quinn, D.; et al. The Differential Expression of EphB2 and EphB4 Receptor Kinases in Normal Bladder and in Transitional Cell Carcinoma of the Bladder. PLoS ONE 2014, 9, e105326. [CrossRef] [PubMed]

74. Oweida, A.; Bhatia, S.; Hirsch, K.; Calame, D.; Griego, A.; Keysar, S.; Pitts, T.; Sharma, J.; Eckhardt, G.; Jimeno, A.; et al. Ephrin-B2 overexpression predicts for poor prognosis and response to therapy in solid tumors. Mol. Carcinog. 2016, 56, 1189-1196. [CrossRef] [PubMed]

75. Li, S.; Zhu, Y.; Ma, C.; Qiu, Z.; Zhang, X.; Kang, Z.; Wu, Z.; Wang, H.; Xu, X.; Zhang, H.; et al. Downregulation of EphA5 by promoter methylation in human prostate cancer. BMC Cancer 2015, 15, 18. [CrossRef]

76. Li, S.; Ma, Y.; Xie, C.; Wu, Z.; Kang, Z.; Fang, Z.; Su, B.; Guan, M. EphA6 promotes angiogenesis and prostate cancer metastasis and is associated with human prostate cancer pro-gression. Oncotarget 2015, 6, 22587-22597. Available online: www.impactjournals. com/oncotarget/ (accessed on 2 August 2021). [CrossRef] [PubMed]

77. Herath, N.I.; Spanevello, M.D.; Sabesan, S.; Newton, T.; Cummings, M.; Duffy, S.; Lincoln, D.; Boyle, G.; Parsons, P.G.; Boyd, A.W. Over-expression of Eph and ephrin genes in advanced ovarian cancer: Ephrin gene expression correlates with shortened survival. BMC Cancer 2006, 6, 144. [CrossRef] [PubMed]

78. Han, L.; Dong, Z.; Qiao, Y.; Kristensen, G.B.; Holm, R.; Nesland, J.M.; Suo, Z. The clinical significance of EphA2 and Ephrin A-1 in epithelial ovarian carcinomas. Gynecol. Oncol. 2005, 99, 278-286. [CrossRef] [PubMed]

79. Chen, X.; Wang, X.; Wei, X.; Wang, J. EphA5 protein, a potential marker for distinguishing histological grade and prognosis in ovarian serous carcinoma. J. Ovarian Res. 2016, 9, 83. [CrossRef] [PubMed]

80. Liu, X.; Xu, Y.; Jin, Q.; Wang, W.; Zhang, S.; Wang, X.; Zhang, Y.; Xu, X.; Huang, J. EphA8 is a prognostic marker for epithelial ovarian cancer. Oncotarget 2016, 7, 20801-20809. [CrossRef]

81. Gao, W.; Zhang, Q.; Wang, Y. EphB3 protein is associated with histological grade and FIGO stage in ovarian serous carcinomas. APMIS 2017, 125, 122-127. [CrossRef]

82. Alam, S.M.; Fujimoto, J.; Jahan, I.; Sato, E.; Tamaya, T. Coexpression of EphB4 and ephrinB2 in tumour advancement of ovarian cancers. Br. J. Cancer 2008, 98, 845-851. [CrossRef]

83. Castellvi, J.; García-Jiménez, A.; de la Torre, J.; Hernandez, J.; Gil-Moreno, A.; Xercavins, J.; Cajal, S.R.Y. Ephrin B expression in epithelial ovarian neoplasms correlates with tumor differentiation and angiogenesis. Hum. Pathol. 2006, 37, 883-889. [CrossRef] [PubMed]

84. Kamat, A.A.; Coffey, D.; Merritt, W.M.; Nugent, E.; Urbauer, D.; Lin, Y.G.; Edwards, C.; Broaddus, R.; Coleman, R.L.; Sood, A.K. EphA2 overexpression is associated with lack of hormone receptor expression and poor outcome in endometrial cancer. Cancer 2009, 115, 2684-2692. [CrossRef] [PubMed] 
85. Alam, S.; Fujimoto, J.; Jahan, I.; Sato, E.; Tamaya, T. Overexpression of ephrinB2 and EphB4 in tumor advancement of uterine endometrial cancers. Ann. Oncol. 2006, 18, 485-490. [CrossRef]

86. Dong, L.-D.; Cheng, X.-L.; Zhou, L.; Huang, Q.; Li, J.-C.; Yi, C.-J. Overexpression of erythropoietin-producing hepatocyte receptor B4 and ephrin-B2 is associated with estrogen receptor expression in endometrial adenocarcinoma. Oncol. Lett. 2017, 13, $2109-2114$. [CrossRef]

87. Wu, D.; Suo, Z.; Kristensen, G.B.; Li, S.; Troen, G.; Holm, R.; Nesland, J.M. Prognostic value of EphA2 and EphrinA-1 in squamous cell cervical carcinoma. Gynecol. Oncol. 2004, 94, 312-319. [CrossRef]

88. Holm, R.; Van de Putte, G.; Suo, Z.; Lie, A.K.; Kristensen, G.B. Expressions of EphA2 and EphrinA-1 in early squamous cell cervical carcinomas and their relation to prognosis. Int. J. Med. Sci. 2008, 5, 121-126. [CrossRef]

89. Gao, Q.; Liu, W.; Cai, J.; Li, M.; Gao, Y.; Lin, W.; Li, Z. EphB2 promotes cervical cancer progression by inducing epithelialmesenchymal transition. Hum. Pathol. 2014, 45, 372-381. [CrossRef]

90. Zhang, S.; Jiang, T.; Liang, M. Expression of Eph B4 and Ephrin B2 in cervical cancer tissues and angiogenesis. Int. J. Gynecol. Obstet. 2007, 96, 46-47. [CrossRef] [PubMed]

91. Megiorni, F.; Gravina, G.L.; Camero, S.; Ceccarelli, S.; Del Fattore, A.; Desiderio, V.; Papaccio, F.; McDowell, H.P.; Shukla, R.; Pizzuti, A.; et al. Pharmacological targeting of the ephrin receptor kinase signalling by GLPG1790 in vitro and in vivo reverts oncophenotype, induces myogenic differentiation and radiosensitizes embryonal rhabdomyosarcoma cells. J. Hematol. Oncol. 2017, 10, 161. [CrossRef] [PubMed]

92. Randolph, M.E.; Cleary, M.M.; Bajwa, Z.; Svalina, M.N.; Young, M.C.; Mansoor, A.; Kaur, P.; Bult, C.J.; Goros, M.W.; Michalek, J.E.; et al. EphB4/EphrinB2 therapeutics in Rhabdomyosarcoma. PLoS ONE 2017, 12, e0183161. [CrossRef]

93. Tang, X.X.; Zhao, H.; Robinson, M.E.; Cohen, B.; Cnaan, A.; London, W.; Cohn, S.; Cheung, N.-K.V.; Brodeur, G.M.; Evans, A.E.; et al. Implications of EPHB6, EFNB2, and EFNB3 expressions in human neuroblastoma. Proc. Natl. Acad. Sci. USA 2000, 97, 10936-10941. [CrossRef] [PubMed]

94. Chetcuti, A.; Aktas, S.; Mackie, N.; Ulger, C.; Toruner, G.; Alkan, M.; Catchpoole, D. Expression profiling reveals MSX1 and EphB2 expression correlates with the invasion capacity of Wilms tumors. Pediatr. Blood Cancer 2011, 57, 950-957. [CrossRef] [PubMed]

95. Janes, P.W.; Vail, M.E.; Gan, H.K.; Scott, A.M. Antibody Targeting of Eph Receptors in Cancer. Pharm. 2020, 13, 88. [CrossRef] [PubMed]

96. Lodola, A.; Giorgio, C.; Incerti, M.; Zanotti, I.; Tognolini, M. Targeting Eph/ephrin system in cancer therapy. Eur. J. Med. Chem. 2017, 142, 152-162. [CrossRef]

97. El-Khoueiry, A.; Gitlitz, B.; Cole, S.; Tsao-Wei, D.; Goldkorn, A.; Quinn, D.; Nieva, J.; Dorff, T.; Oswald, M.; Berg, J.; et al. A first-in-human phase I study of sEphB4-HSA in patients with advanced solid tumors with expansion at the maximum tolerated dose (MTD) or recommended phase II dose (RP2D). Eur. J. Cancer 2016, 69, S11. [CrossRef] 